\title{
Natural-Based Biomaterial for Skin Wound Healing (Gelatin vs. Collagen): Expert Review
}

\author{
Ruth Naomi $^{1}\left(\mathbb{D}\right.$, Hasnah Bahari ${ }^{1}\left(\mathbb{D}\right.$, Pauzi Muhd Ridzuan $^{2}$ and Fezah Othman ${ }^{3, *}$ (D) \\ 1 Department of Human Anatomy, Universiti Putra Malaysia, Serdang 43400, Selangor, Malaysia; \\ ruthmanuel2104@gmail.com (R.N.); haba@upm.edu.my (H.B.) \\ 2 Estika Research Centre, Kuala Terengganu 21080, Terengganu, Malaysia; drpmridzuan@gmail.com \\ 3 Department of Biomedical Sciences, Faculty of Medicine and Health Sciences, Universiti Putra Malaysia, \\ Serdang 43400, Selangor, Malaysia \\ * Correspondence: fezah@upm.edu.my; Tel.: +60-11-1071-8590
}

check for updates

Citation: Naomi, R.; Bahari, H.;

Ridzuan, P.M.; Othman, F.

Natural-Based Biomaterial for Skin Wound Healing (Gelatin vs. Collagen): Expert Review. Polymers 2021, 13, 2319. https://doi.org/ $10.3390 /$ polym 13142319

Academic Editor: Anamarija Rogina

Received: 13 May 2021

Accepted: 11 June 2021

Published: 14 July 2021

Publisher's Note: MDPI stays neutral with regard to jurisdictional claims in published maps and institutional affiliations.

Copyright: (c) 2021 by the authors. Licensee MDPI, Basel, Switzerland. This article is an open access article distributed under the terms and conditions of the Creative Commons Attribution (CC BY) license (https:// creativecommons.org/licenses/by/ $4.0 /)$.

\begin{abstract}
Collagen $(\mathrm{Col})$ and gelatin are most extensively used in various fields, particularly in pharmaceuticals and therapeutics. Numerous researchers have proven that they are highly biocompatible to human tissues, exhibit low antigenicity and are easy to degrade. Despite their different sources both Col and gelatin have almost the same effects when it comes to wound healing mechanisms. Considering this, the bioactivity and biological effects of both $\mathrm{Col}$ and gelatin have been, and are being, constantly investigated through in vitro and in vivo assays to obtain maximum outcomes in the future. With regard to their proven nutritional values as sources of protein, Col and gelatin products exert various possible biological activities on cells in the extracellular matrix (ECM). In addition, a vast number of novel $\mathrm{Col}$ and gelatin applications have been discovered. This review compared $\mathrm{Col}$ and gelatin in terms of their structures, sources of derivatives, physicochemical properties, results of in vitro and in vivo studies, their roles in wound healing and the current challenges in wound healing. Thus, this review provides the current insights and the latest discoveries on both Col and gelatin in their wound healing mechanisms.
\end{abstract}

Keywords: collagen; gelatin; wound healing; in vitro and in vivo; biomaterials scaffolds; physicochemical property

\section{Biomaterials}

Biomaterials are substitutes for biological tissues in the human body that have the ability to interact with the body. They can either be natural or synthetic. For more than 50 years, biomaterials have been developed to be used in the therapeutic field [1]. Approximately, the annual growth rate for biomaterials in the global market is $15.97 \%$ and by the year 2027 it is expected to hit up to USD 348.4 billion in value [2]. Being natural biomaterials, both collagen ( $\mathrm{Col}$ ) and gelatin have shown promising results for skin wound healing. With regard to this statement, $\mathrm{Col}$ and gelatin are highly biocompatible toward human tissues as they resemble the extracellular matrix [3,4]. This property makes both of these materials the main choices for implantable medical products for in vitro testing [5]. Gelatin is the hydrolysed form of $\mathrm{Col}$ and both of them have the same amino acids, but their chemical properties differ.

\subsection{Collagen}

Col is a fibrous protein consisting of more than 1000 amino acids and is a substitute for cell scaffolding in the human body. It is essential for cell signaling, resilience for multicellular organisms and resistance to mechanical stress. In humans, Col is the most predominant protein as it makes up the major component of the extracellular matrix (ECM) [6]. Col can either exist as a homotrimer or a heterotrimer, depending on the composition of the $\alpha$-chains. To date, there are 29 types of $\mathrm{Col}$ which have been identified. 
Among them, Col type I (Col-I) is the most abundant form widely incorporated into therapeutics, due to its high biocompatibility and low immunogenicity [7]. It makes up $90 \%$ of the human skin composition [8] and 30\% of bodily proteins [6]. The structure of $\mathrm{Col}$ appears in a triple-helical domain, self-twisted into a rope-like structure. It consists of repeating triplets of Gly-X-Y, with glycine being constant, while $\mathrm{x}$ and $\mathrm{y}$ can be either proline or hydroxyproline. This structure is held together by hydrogen bonds which ensure its stability. This bond is highly resistant to cleavage which can only be disrupted by the presence of collagenase [8]. Such characteristics further contribute to Col being widely used in the medical field. However, Col can still induce a very low amount of antigenicity. However, this can be overcome through crosslinking the Col by removing the telopeptide molecules [9]. Naturally, the binding of Col with glycoprotein prevents the rise of an immune response toward $\mathrm{Col}$ in the body. Col has the ability to control the cycle of cell migration, proliferation, and differentiation through the action of fibroblasts. In the preparation of a low molecular weight of $\mathrm{Col}$, the high cost, presence of impurities, enzymatic degradation, poor elasticity and degree of crosslinking are great challenges which could hinder its incorporation in certain fields [10].

\subsection{Gelatin}

Gelatin is a natural polymer that can be derived from nonsoluble Col through hydrolysis [11]. Since gelatin is a Col derivative, it possesses almost the same characteristics as Col. Gelatin is proven to be biocompatible to human tissues, flexible, stable and can be modified to act as a scaffold base [12]. Gelatin comprises of proline, glycine and hydroxyproline [11] and is similar in the composition of amino acids as Col, mimicking the extracellular matrix [13]. The composition of glycine amino acid in the gelatin is responsible for the adherence of cells [14]. The structure of gelatin mainly depends on the extraction process. However, it consists of randomized macromolecular and heterogeneous structures with a poor melting point. [11]. Human tissue has the ability to metabolise gelatin and this is the main reason for gelatin becoming one of the choices in the pharmaceutical industry. Its function can always be customized and it does not trigger any immune response in the human body [15]. Due to these unique characteristics, gelatin is in high demand in the global market, which was approximately 412.7 kilotons in 2015, with pigskin being the primary source of gelatin extraction [16]. Based on the process of extraction, gelatin can be categorized into two types, namely, type A and type B. Type A (positively charged) refers to acid extraction, while type B (negatively charged) refers to alkaline extraction $[17,18]$. During extraction, the generated isoelectric point and variation enhance the binding of the gelatin to the charged therapeutic agents [19]. The isoelectric point for type A and B gelatins are usually at $\mathrm{pH} 9$ and $\mathrm{pH} 5$, respectively, [14]. Gelatin can be obtained from a very low cost commercially available source and possesses a high range of biodegradability [20]. The drying temperature of gelatin influences its properties and it possesses a perfect film-forming property. This makes gelatin suitable to be widely used as a drug delivery substance. Moreover, gelatin is known to be a barrier against gas and hydrophilicity, although it exhibits poor mechanical strength [21]. However, the rapid degradation of gelatin in a colloidal solution and at $37^{\circ} \mathrm{C}$ still remains a challenge in biomedical applications [22]. However, the adverse effects of gelatins can be influenced by crosslinking agents [16].

\section{Differences between Collagen and Gelatin}

Both Col and gelatin are natural biomaterials that are being widely used as therapeutics, particularly in skin wound healing. However, some differences exist which make one superior to the other. The differences are presented in Table $1[10,23-30]$. 
Table 1. Differences between collagen and gelatin.

\begin{tabular}{|c|c|c|}
\hline Property & Collagen & Gelatin \\
\hline Origin & Animals/humans & Col from bones/skin \\
\hline Precursor & Fibroblast & Col type I \\
\hline Physical characteristics & $\begin{array}{l}\text { Elastic, tough and versatile } \\
\text { structural protein }\end{array}$ & Smooth and gel like substances \\
\hline Number of Amino acids & Approximately 1050 & Less than 20 \\
\hline Structure of peptide & $\begin{array}{c}\text { Triple helix of } \\
\text { polypeptide chain }\end{array}$ & Small peptides \\
\hline Types & $\begin{array}{l}\text { Fibril-forming and } \\
\text { nonfibril forming }\end{array}$ & $\mathrm{A}$ and $\mathrm{B}$ \\
\hline Aromatic radicals & Present & Absent \\
\hline Solubility & $\mathrm{NaCI}$ solution/dilute acid & $\mathrm{H}_{2} \mathrm{O}$ \\
\hline Mechanical strength & Poor & Poor \\
\hline Antigenic response & $\begin{array}{c}\text { Possible, in case of } \\
\text { crosslinking/integration with } \\
\text { antibacterial agent }\end{array}$ & $\begin{array}{l}\text { Impossible, Because of its } \\
\text { hydrophilicity nature. }\end{array}$ \\
\hline Digestion & Difficult & Easy \\
\hline Protease & Resistant & Susceptible \\
\hline Gelling properties & No & Yes \\
\hline In vitro degradation & $\begin{array}{c}\text { Serine protease, pepsin-cleaving } \\
\text { enzyme, gelatinease } \\
\text { and collagenase }\end{array}$ & Collagenase \\
\hline In vivo degradation & Endopeptidase & MMP-2 and MMP-9 \\
\hline Disease transmission & $\begin{array}{l}\text { Xenozoonoses if the Col } \\
\text { is impure }\end{array}$ & Not encountered \\
\hline Usage & $\begin{array}{c}\text { Burns, hemostasis, tissue } \\
\text { defects, regeneration of nerves, } \\
\text { wound dressings, augmentation } \\
\text { of soft tissue, artificial dermis } \\
\text { skin replacement }\end{array}$ & $\begin{array}{l}\text { Adhesive of soft tissues, } \\
\text { artificial skin, regeneration of } \\
\text { nerves, wound dressings }\end{array}$ \\
\hline
\end{tabular}

\subsection{Sources of Collagen and Gelatin}

There is a vast range of sources that could be used to extract $\mathrm{Col}$ and gelatin. Although the source of derivatives influences the outcome, it still can be modified according to the medical needs. Col is commercially available and can be extracted literally from any sources, even from 75-million-year-old preserved dinosaur tissues [28]. Similarly, since gelatin is a Col derivative, the process of obtaining and the sources of gelatin are also wide. The sources of Col and gelatin are summarized in Table 2 [16,29-42].

\subsection{Physicochemical Properties of Collagen and Gelatin for Skin Wound Healing}

Collagen and gelatin exhibit properties that are suitable to accelerate skin wound healing. Although both are approved natural biomaterials for skin wound healing, yet their biological properties greatly differ from one another. Yet, both can be ideal biomaterials for skin wound healing. The properties of $\mathrm{Col}$ and gelatin are discussed below.

\subsubsection{Thermal Resistance}

Thermal resistance indicates the ability of the scaffold to be resistant to heat. This is essential to ensure that the elasticity, toughness and strength of the scaffold is maintained upon changes in the temperature. The functionality of the biomaterial must be preserved at the wound site. The transition temperature for acid-soluble Col $\left(115.33 \pm 0.97^{\circ} \mathrm{C}\right)$ 
and pepsin-soluble $\mathrm{Col}\left(112.1 \pm 0.79{ }^{\circ} \mathrm{C}\right)$ is highest at a heating rate of $2{ }^{\circ} \mathrm{C} \mathrm{min}-1$. The maximum transition temperature was recorded at 39.6 and $110.7^{\circ} \mathrm{C}$ for acid-soluble Col, while for pepsin-soluble Col, it was at 38.33 and $109{ }^{\circ} \mathrm{C}$. At the same time, heating for $0.5 \mathrm{~min}^{-1}$ was recorded at 39.6 and $38.33^{\circ} \mathrm{C}$ for acid-soluble Col and pepsin-soluble Col, respectively [43]. In contrast, gelatin designed in the form of a gel was proven to be completely thermo reversible. The melting point for gelatin was recorded at $16{ }^{\circ} \mathrm{C}$, while the gelling temperature was at $5{ }^{\circ} \mathrm{C}$ [44].

Table 2. Different sources of collagen and gelatin.

\begin{tabular}{|c|c|c|}
\hline Protein & Gelatin & Collagen \\
\hline Sources & $\begin{array}{l}\text { Mammalian, porcine, bovine, } \\
\text { bone, fish skin (Labeo rohita), } \\
\text { insects, cattle bones, hides, } \\
\text { chicken, fins, sea urchin, jelly } \\
\text { fish, bird feet (Encephalopat), } \\
\text { camel skin, corn plant } \\
\text { and seaweed. }\end{array}$ & $\begin{array}{l}\text { Bovine, fish, porcine, sponges, } \\
\text { jellyfish, star fish, prawn, sea } \\
\text { urchin, squid, sea anemone, } \\
\text { octopus, cuttlefish, bone } \\
\text { (Thunnus obesus, skipjack tuna, } \\
\text { japanese sea-bass, yellow sea } \\
\text { bream, horse mackerel, } \\
\text { Oreochromis niloticas), ovine } \\
\text { tendon, buffalo skin, tobacco } \\
\text { plant, yeast (Saccharomyces } \\
\text { cerevisiae and Pichia pastoris), } \\
\text { bacteria (Escherichia Coli) } \\
\text { and insects. }\end{array}$ \\
\hline Extraction methods & $\begin{array}{l}\text { Alkaline hydrolysis, acid } \\
\text { hydrolysis, thermal extraction } \\
\text { and high pressure processing. }\end{array}$ & $\begin{array}{l}\text { Chemical hydrolysis, enzymatic } \\
\text { hydrolysis, acidic/ salting out, } \\
\text { alkaline extraction and } \\
\text { acidic extraction. }\end{array}$ \\
\hline Composition & $\begin{array}{l}\text { The amino acid composition } \\
\text { differs depending on the } \\
\text { source of derivative. }\end{array}$ & $\begin{array}{l}\text { The extraction method and the } \\
\text { source of Col influence the } \\
\text { Col physicochemical properties. }\end{array}$ \\
\hline Crosslinking & \multicolumn{2}{|c|}{ Physical, chemical and enzymatic } \\
\hline
\end{tabular}

\subsubsection{Chemical Stability}

The chemical stability of any biomaterial scaffold is essential for its functional stability and this is usually confirmed through Fourier transform infrared spectroscopy (FTIR). A uniformity in the major absorption band indicates scaffold stability [45]. FTIR for Col was recorded at $1632 \mathrm{~cm}^{-1}, 1548 \mathrm{~cm}^{-1}$ and $1237 \mathrm{~cm}^{-1}$ for amide I, amide II and amide III, respectively. The major absorption band was recorded at $2923 \mathrm{~cm}^{-1}$, indicating uniform $\mathrm{CH}_{2}$ stretching [46]. As for gelatin, the major absorption bands were seen at $3433 \mathrm{~cm}^{-1}$, $1630 \mathrm{~cm}^{-1}, 1565 \mathrm{~cm}^{-1}$ and $1240 \mathrm{~cm}^{-1}$ for amide A, amide I, amide II and amide III, respectively. The recorded major absorption band for gelatin ranged from $1460 \mathrm{~cm}^{-1}$ to $1380 \mathrm{~cm}^{-1}$, which highly corresponded to the presence of the methyl group [32].

\subsubsection{Mechanical Strength}

An ideal scaffold must be able to withstand force, particularly a scaffold that has been designated for wound healing. In this scenario, mechanical strength determines whether a scaffold is able to withstand the force or not [47]. Ghodbane et al., (2016) stated that the ultimate stress values of ovine, bovine, and porcine were recorded at $15.08 \mathrm{kPa} \pm 15.08 \mathrm{kPa}$, $12.33 \mathrm{kPa} \pm 2.37 \mathrm{kPa}$ and $13.91 \mathrm{kPa} \pm 3.11 \mathrm{kPa}$, respectively. In addition, the strain percentage and tensile toughness for Col were $50.74 \% \pm 4.02 \%$ and $3.32 \mathrm{~kJ} / \mathrm{m}^{3} \pm 0.81 \mathrm{~kJ} / \mathrm{m}^{3}$ [48]. A study done by Xing et al., (2014) [49] described that unpurified gelatin exhibited better mechanical strength in comparison to purified gelatin. As reported by them, the average storage and loss of modulus of the gelatin were $2.83 \pm 0.10$ fold and $3.80 \pm 0.43$ fold, while the ultimate stress was recorded as $107 \mathrm{kPa} \pm 25 \mathrm{kPa}$ [49]. 


\subsubsection{Oxygen Barrier}

An ideal scaffold must be greatly permeable to allow the diffusion of oxygen to enhance the wound healing mechanism [50]. An adequate pore size of the scaffold determines this property of the scaffold. For adult skin healing, the optimal pore size has been determined to be in the range of $20 \mu \mathrm{m}$ to $125 \mu \mathrm{m}$ [51]. As stated by Ghodbane et al., (2016) [48], Col derived from ovine, bovine and porcine sources exhibited average mean pore sizes of $73.05 \mu \mathrm{m} \pm 10.79 \mu \mathrm{m}, 85.84 \mu \mathrm{m} \pm 9.51 \mu \mathrm{m}$ and $87.32 \mu \mathrm{m} \pm 10.69 \mu \mathrm{m}$, respectively. All Col scaffolds display heterogenous architectures, despite the sources of the derivative [48], while gelatin scaffolds display open pore structures, highly interconnected and widely tuneable. In addition, the pore size of gelatin can be altered according to the specific need by using ice particulates without affecting its mechanical property [52].

\subsubsection{Water Vapor Transmission Rate (WVTR)}

The WVTR directly corresponds to the ability of the scaffold to retain moisture in accordance with the need of the skin-healing phase. In relation to this, $2028.3 \pm 237.8 \mathrm{~g} / \mathrm{m}^{2} /$ day has proven to be an ideal value to retain the moisture environment at the injury site to promote healing [53]. Col shows a WVTR of s $4750 \pm 700.209 \mathrm{~g} / \mathrm{m}^{2} /$ day [54] while for gelatin it is $1040 \pm 95 \mathrm{~g} / \mathrm{m}^{2} /$ day [55].

\subsubsection{Biocompatibility}

The main purpose of designing a scaffold is to promote the migration and proliferation of the cells toward the scaffold in order to promote healing. This can only be achieved if the designed scaffold is compatible to human cells. Mousavi et al., (2019) described that $\mathrm{Col}$ enhanced the binding of cells toward the scaffold through integrin binding and the presence of a cell-producing enzyme which was capable of breaking it down directly. This is possible due to the existence of the amino acid sequence in the backbone of Col, arginine-glycine-aspartic acid, which is similar to that in the human body. As a result, cell adhesion and proliferation are accelerated [54]. Meanwhile, gelatin scaffolds have been proven to have no significant effect on cell proliferation and cytotoxicity against human adipose-derived mesenchymal stem cells (hASCs. In view of this, gelatin is also categorized as a compatible biomaterial for human cells [56].

\subsubsection{Biodegradability}

To ensure a proper remodelling process, the scaffold must be able to degrade in an appropriate time. Since serine protease and collagenase can degrade Col naturally through intracellular degradation, it is thus controlled locally by engineered tissue cells. At the same time, metalloproteinases (MMPs) secreted by the inflammatory cells in the human body can degrade the $\mathrm{Col}$ (extracellular degradation) [57]. Meanwhile, gelatin degradation duration ranges from 35 days to 63 days in the presence of lysine diisocyanate ethyl ester [58].

\subsubsection{Immune Response}

The stimulation of an immune response is a very relevant issue when it comes to a biomaterial. An ideal biomaterial should not trigger any immune reaction by the host tissue. In relation to this, Col induces a very small amount of immune reaction when a scaffold is newly being placed onto the human skin. This happens depending on the source of the extracted Col, crosslinking agent or the presence of remnants of cells [58]. However, this can be overcome by removing the terminal telopeptide from the Col molecule. Upon the removal of that particular structure, the arrangement of the Col fibril pattern is disrupted, leading to an amorphous structure. When this happens, the surface of Col becomes highly soluble due to the positive electrons, eliminating the immunogenicity property of the Col scaffold [59]. Meanwhile, gelatin is proven to stimulate immunogenicity in the host tissue too. However, this is two-fold lower compared to Col. Specifically, when gelatin is crosslinked, a covalent bond is formed. This in turn creates a second network locked in place by chemical bonds [60]. It is widely speculated that biomaterials must be covalently 
attached to a bigger protein in order to elicit an immune response [61]. A covalent bond can become securely bound to a carrier molecule, most commonly a protein, if it exists. The hapten-carrier complex induces antibody formation, and so becomes immunogenic. The hapten then reacts with the antibodies that have been produced against it, causing an immunological or allergic response [62]. Introducing a covalent net point to gelatin manifested in it suppressing its immunogenicity property [58].

\subsubsection{Antibacterial Property}

Integrating an antibacterial effect into a biomaterial is an essential component in preventing the entrance and colonisation by microbes at the injury site. Native Col does not possess antibacterial properties. Hence, the incorporation of an antibacterial effect in $\mathrm{Col}$ further contributes to its physicochemical characteristics. Col can be integrated with silver nanoparticles (AgNP) [63], collagencin [64], epoxidized safrole [65], polyhexamethylene biguanide [66], titanium dioxide [67], etc. Similarly, native gelatin does not show any antibacterial effect. However, to give it such an effect, gelatin can be easily integrated with Ginkgo biloba extract [68], D-Limonene [69], Finibax [70], black pepper oleoresin [71], etc.

\subsubsection{Hemostatic Effect}

Hemostasis (stoppage of bleeding) is the primary component in wound healing. In this, native Col plays a vital role as a hemostatic agent as it serves as a major activator for immediate platelet response when there is injury. Furthermore, it allows the platelets to adhere at the wound site, forming a clump or clot together to stop the bleeding [72]. At the same time, this property can be further improved by integrating Col scaffold with oxidized microcrystalline cellulose [73]. On the other hand, gelatin does stimulate the hemostatic process by hastening the development of thrombus and providing it with a structural support. Within two days and up to six weeks, gelatin scaffold has proven to be absorbed or liquefies upon being utilized as a hemostatic agent. In comparison to Col, gelatin has been shown to be a superior hemostatic agent [74].

\subsubsection{Cytotoxicity}

Cytotoxic is an important parameter to be considered when it comes to a biomaterial. It determines whether the scaffold supports cell viability or not. Col has been proven to not induce cytotoxic effects, particularly in human cells. Instead, Col aids in cell delivery and distribution by creating a microenvironment for the uniform spreading and proliferation of cells [75]. Similarly, native gelatin does not exhibit any form of cytotoxic effect upon being seeded with keratinocytes. However, the method of gelatin extraction can trigger cytotoxic effects in the gelatin scaffold. For instance, $>0.5 \mathrm{mg} / \mathrm{mL}$ enzymatic extraction could trigger the cytotoxic effect [76].

\subsubsection{Cell Proliferation}

Cell growth is an essential element in wound healing. With regard to this, the native col scaffold has been proven effective for cell attachment and proliferation, particularly at the wound site. Interestingly, the cells at the wound site appeared to be symmetrical and aligned in accordance with the native Col scaffold [77]. Nonetheless, an in vitro study proved that col scaffolds successfully accelerated healing by enhancing proliferation of fibroblasts [78] by increasing biological and structural integrities which resembled the native extracellular matrix (ECM) at the wound site [79]. In contrast, gelatin has been classified as a biofriendly scaffold which interacts perfectly with adipocytes, keratinocytes, cerebellum stem cells, and pre-osteoblasts, due to its similar structure to ECM. So the gelatin scaffold is able to enhance the vascularization process within the newly engineered tissues at the healing site [56]. 


\section{Roles of Collagen and Gelatin in Wound Healing Phases}

Col makes up the major component of the extracellular matrix (ECM) in humans [4] while gelatin is a Col derivative [12]. Col is a perfectly organized structure as a threedimensional (3D) scaffold that surrounds the cells. Thus, it has a dominant influence in maintaining the structural and biological integrity of the ECM. Being a natural component of the human body, it has been categorized as one of the major biomaterials widely used in wound healing [4]. Nonetheless, the physicochemical properties of Col and gelatin greatly influence the mechanism of skin wound healing.

$\mathrm{Col}$ and gelatin can penetrate into lipid free interferences (membranes) and are surfaceactive molecules $[80,81]$. In addition, they are thermally and chemically stable with high tensile strength, permeable to $\mathrm{O}_{2}$, highly biocompatible, regardless of the source of the derivative, biodegradable, weakly antigenic and hemostatic agents. They have the ability to form high tensile, stabilized fibers through self-aggregation and crosslinking. These fibers can be modified into any form of scaffolding [63]. Particularly in skin injury, Col primarily, acts as a chemotactic agent by creating a microenvironment for the initiation of the healing mechanism (inflammatory phase) as it forms a protective barrier for the skin [82]. Similarly, gelatin is able to act as a hemostatic agent to initiate the wound healing mechanism and to absorb exudates present at the wound region while creating a suitable microenvironment for the inflammatory phase to take place [83].

In the proliferative phase, the wound bed prepares for the growth of new tissues and the wound undergoes contraction. In this phase, $\mathrm{Col}$ aids the growth of new tissues and accelerates the deposition of granulation tissues [84]. At the same time, Col enhances the activity of fibroblasts, leading to a drastic increase in the fibroblast proliferation rate. By means of contraction, Col forms a network that reinforces the adhesion of cells and tissue integrity [85]. As for gelatin, it acts as a porous scaffold to stimulate the migration of cells, specifically fibroblasts to the injury site. It further enhances the formation of new tissues by providing structural and mechanical strength at the wound site [83]. In the maturation phase, the continuity of the skin begins and the process of re-epithelisation continues [84]. In this process, Col supplies adequate nutrition directly to the wound, enhancing the repair mechanism and aiding in scar reduction [86].

\section{Collagen and Gelatin for Skin Wound Healing}

To date there is numerous scientific research on the effectiveness of including Col and gelatin in skin wound healing. Being biocompatible, they are beneficial and superior compared to other available natural products. Col is naturally found in the human body while gelatin is a hydrolysed form of Col. Studies done by Dill and Morgelin (2020) [77] and Wiegand et al., (2016) [87] showed that native Col provided a 3D microenvironment that stimulated cell proliferation and aided the migration of keratinocytes and fibroblasts to the physiologic locations during wound healing. Through their in vitro investigations, they noticed that fibroblasts and keratinocytes attached to Col with high affinities. Similarly, Jridi et al., (2015) [88] observed that positive interaction existed between Col and human cells, leading to an increased level of hydroxyproline at the injury site. With regard to this, in vivo experiments carried out by Dang et al., (2015) [89], Chen et al., (2019) [90], Ke et al., (2015) [91], and Helary et al., (2015) [92] further proved that Col had the capacity to increase cellularity, granulation tissues, expressions of EGF, FGF, and CD31, collagenization, neovascularization and re-epithelization. This thereby resulted in rapid healing at the injury site. Interestingly, there was no immune response observed, despite the varying sources of the Col derivatives used in the in vivo testing. The outcomes clearly indicated that Col derivatives of any source were highly biocompatible to humans, due to their integrin (RGD) components [10]. Table 3 shows the in vitro and in vivo evidence of native collagen for skin wound healing.

Similarly, native gelatin showed good adhesion to fibroblasts and cell viability from $72 \mathrm{~h}$ up to 7 days $[93,94]$. The in vivo studies done by Hsu et al., (2019) [95], Nikpasand et al., (2019) [96], and Jang et al., (2017) [97] indicated the formation of thick granulation tissues, 
increased re-epithelization and blood vessel formation with an absence of cytotoxic effects confirmed through CCK-8 assays. For both Col and gelatin scaffolds, the analysed physicochemical properties correlated with those of an ideal scaffold for wound healing as per discussed in the physicochemical section above. No contraindication outcome was observed in the usage of $\mathrm{Col}$ and gelatin for skin wound healing. Table 4 shows the in vitro and in vivo evidence of native gelatin for skin wound healing.

Table 3. In vitro and in vivo studies of native collagen for skin wound healing.

\begin{tabular}{|c|c|c|c|c|c|c|}
\hline Author & Objective & $\begin{array}{c}\text { Study } \\
\text { Design }\end{array}$ & Subject & Duration & Outcome & Conclusion \\
\hline $\begin{array}{l}\text { Dill et al., } \\
\text { (2020) [77] }\end{array}$ & $\begin{array}{l}\text { To access the } \\
\text { efficacy of native } \\
\text { Col template in } \\
\text { wound healing }\end{array}$ & In vitro & $\begin{array}{l}\text { Keratinocytes } \\
\text { and fibrob- } \\
\text { lasts cells }\end{array}$ & $\begin{array}{l}15 \mathrm{~min} \text { to } \\
180 \mathrm{~min}\end{array}$ & $\begin{array}{l}\text { - Large amount of filopodia found arise from } \\
\text { the cell body and attach to the Col scaffold. } \\
\text { Attachment of keratinocytes and fibroblasts } \\
\text { to the scaffold increased drastically over time. } \\
>30 \text { min, maximum spreading of cells with } \\
\text { well-defined morphology was seen. }\end{array}$ & $\begin{array}{l}\text { Col scaffold able to } \\
\text { stimulate cell } \\
\text { proliferation and } \\
\text { aids the migration } \\
\text { of keratinocytes and } \\
\text { fibroblasts to the } \\
\text { physiologic } \\
\text { locations during } \\
\text { wound healing. }\end{array}$ \\
\hline $\begin{array}{l}\text { Wiegand et al., } \\
\text { (2016) [87] }\end{array}$ & $\begin{array}{l}\text { To evaluate the } \\
\text { effectiveness of } \\
\text { native Col matrix } \\
\text { (NCM) } \\
\text { in wound healing }\end{array}$ & In vitro & $\begin{array}{l}\text { NIH-3T3 } \\
\text { fibrob- } \\
\text { lasts cells }\end{array}$ & $\begin{array}{l}1 \mathrm{~h} \text { to } \\
14 \text { days }\end{array}$ & $\begin{array}{ll}\text { - } & \text { Atomic force microscopy revealed that NCM } \\
\text { fibril similar to human dermis's } \\
\text { microstructure. } \\
\text { NCM exhibit open, single porous structure } \\
\text { - } \\
\text { under scanning electron microscopy (SEM). } \\
\text { - } \quad \text { Drastic increase in fibroblast was observed by } \\
\text { day } 14 \text {. } \\
\text { NCM binds with matrix metalloproteinases-2 } \\
\text { (MMP-2) with high affinity. } \\
\text { - } \quad \text { Stabilization of growth factor (GF) was seen. }\end{array}$ & $\begin{array}{l}\text { Col provides a 3D } \\
\text { microenvironment } \\
\text { that promote } \\
\text { ingrowth of } \\
\text { fibroblasts, } \\
\text { migration and } \\
\text { cell proliferation }\end{array}$ \\
\hline $\begin{array}{l}\text { Jridi et al., } \\
\text { (2015) [88] }\end{array}$ & $\begin{array}{l}\text { To evaluate the } \\
\text { efficacy of Col gel } \\
\text { in wound healing }\end{array}$ & In vivo & $\begin{array}{l}18 \text { female } \\
\text { Wistar rats }\end{array}$ & $\begin{array}{l}\text { Up to } \\
12 \text { days }\end{array}$ & $\begin{array}{ll}\text { - } & \text { SEM showed thick dense fiber with low } \\
\text { porosity. } \\
\text { - }\end{array}$ & $\begin{array}{l}\text { Col can rebalance } \\
\text { the environment in } \\
\text { chronic wound, } \\
\text { thereby enhancing } \\
\text { rapid } \\
\text { wound healing. }\end{array}$ \\
\hline $\begin{array}{l}\text { Dang et al., } \\
\text { (2015) [89] }\end{array}$ & $\begin{array}{l}\text { To access the } \\
\text { efficacy of Col } \\
\text { from haddock } \\
\text { skin for } \\
\text { wound healing }\end{array}$ & In vivo & $\begin{array}{l}18 \text { male } \\
\text { Balb/c mice }\end{array}$ & $\begin{array}{l}\text { Up to } \\
22 \text { days }\end{array}$ & $\begin{array}{l}\text { - UV absorbance spectrum indicated the } \\
\text { presence of polypeptide chains and aromatic } \\
\text { amino acids. } \\
\text { Absorbance of FTIR showed the existence of } \\
\text { stronger hydrogen bond. } \\
\text { Denaturation temperature recorded at } 24.9^{\circ} \mathrm{C} \\
\text { - } \quad \text { and endothermic peak at } 47.6^{\circ} \mathrm{C} \text {. } \\
\text { Decrease in bleeding and clotting time } \\
\text { was seen. } \\
\text { Increase in cellularity, quantity and maturity } \\
\text { of epidermal layer and blood vessels } \\
\text { was seen. }\end{array}$ & $\begin{array}{l}\text { Col shows positive } \\
\text { outcome for scalded } \\
\text { skin healing }\end{array}$ \\
\hline $\begin{array}{l}\text { Chen et al., } \\
\text { (2019) [90] }\end{array}$ & $\begin{array}{l}\text { To access the } \\
\text { efficacy of fish } \\
\text { Col in } \\
\text { wound healing }\end{array}$ & In vivo & $\begin{array}{l}63 \text { female } \\
\text { SD rats }\end{array}$ & $\begin{array}{l}3,7 \text { and } \\
\text { day } 14\end{array}$ & $\begin{array}{ll}\text { - } & \text { Increased level of hydroxyproline in the } \\
\text { treatment group. } \\
\text { - } \quad \text { Granulation tissue formation and fibroblasts } \\
\text { increased in Col group. } \\
\text { - } \quad \text { Reduction in inflammation and increase in } \\
\text { re-epithelization was seen. } \\
\text { - } \quad \text { Expression of EGF, FGF, and CD31 was seen } \\
\text { in the treated group. } \\
\text { - Complete wound closure was seen in day } 14 .\end{array}$ & $\begin{array}{l}\text { Regardless of } \\
\text { method of } \\
\text { extraction, Col } \\
\text { accelerates wound } \\
\text { healing process. }\end{array}$ \\
\hline $\begin{array}{l}\text { Ke et al., } \\
\text { (2015) [91] }\end{array}$ & $\begin{array}{l}\text { To access the } \\
\text { effectiveness of } \\
\text { Col sponge } \\
\text { integrated with } \\
\text { skin-derived } \\
\text { precursors for } \\
\text { skin } \\
\text { wound healing }\end{array}$ & In vivo & $\begin{array}{l}\text { Male } \\
\text { C57BL/6J mice }\end{array}$ & $\begin{array}{l}\text { Up to } \\
14 \text { days }\end{array}$ & 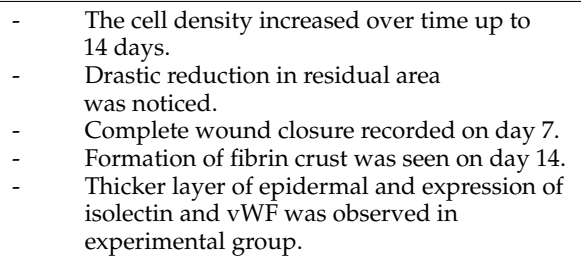 & $\begin{array}{l}\text { Col sponge } \\
\text { integrated with } \\
\text { skin-derived } \\
\text { precursors } \\
\text { accelerates healing } \\
\text { mechanism through } \\
\text { paracrine secretion. }\end{array}$ \\
\hline
\end{tabular}


Table 3. Cont

\begin{tabular}{|c|c|c|c|c|c|c|}
\hline Author & Objective & $\begin{array}{c}\text { Study } \\
\text { Design }\end{array}$ & Subject & Duration & Outcome & Conclusion \\
\hline $\begin{array}{l}\text { Helary et al., } \\
\text { (2015) [92] }\end{array}$ & $\begin{array}{l}\text { To study the } \\
\text { effectiveness of } \\
\text { dense Col matrix } \\
\text { for chronic } \\
\text { wound healing }\end{array}$ & In vivo & $\begin{array}{l}12 \text { adult } \\
\text { Wistar } \\
\text { male rats }\end{array}$ & $\begin{array}{l}15 \text { and } \\
\text { day } 30\end{array}$ &  & $\begin{array}{l}\text { Col accelerates the } \\
\text { healing mechanism } \\
\text { in chronic } \\
\text { wound model. }\end{array}$ \\
\hline $\begin{array}{l}\text { Wang et al., } \\
\text { (2020) [98] }\end{array}$ & $\begin{array}{l}\text { To study the } \\
\text { effect of dermal } \\
\text { Col matrix in full } \\
\text { thickness } \\
\text { skin wound }\end{array}$ & $\begin{array}{l}\text { In vitro } \\
\text { and } \\
\text { in vivo }\end{array}$ & $\begin{array}{l}\text { L929 } \\
\text { fibroblast } \\
\text { cells, } 3 \\
\text { rabbits, } 20 \\
\text { mice and } \\
40 \text { rats }\end{array}$ & $\begin{array}{l}\text { Up to } \\
90 \text { days }\end{array}$ & 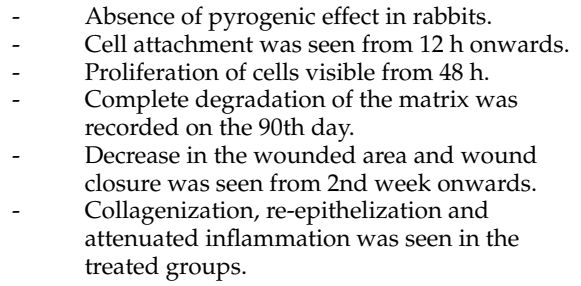 & $\begin{array}{l}\text { Col matrix can } \\
\text { serve as a dermal } \\
\text { substitute and is } \\
\text { able to regenerate } \\
\text { full thickness } \\
\text { skin loss. }\end{array}$ \\
\hline $\begin{array}{l}\text { Akturk et al., } \\
\text { (2016) [99] }\end{array}$ & $\begin{array}{l}\text { To access the } \\
\text { efficiency of Col } \\
\text { in skin } \\
\text { wound healing }\end{array}$ & $\begin{array}{l}\text { In vitro } \\
\text { and } \\
\text { in vivo }\end{array}$ & $\begin{array}{l}3 \mathrm{~T} 3 \\
\text { fibroblasts, } \\
\text { HaCat } \\
\text { keratinocytes } \\
\text { and } 40 \text { male } \\
\text { Wistar } \\
\text { albino rats }\end{array}$ & Up day 14 & 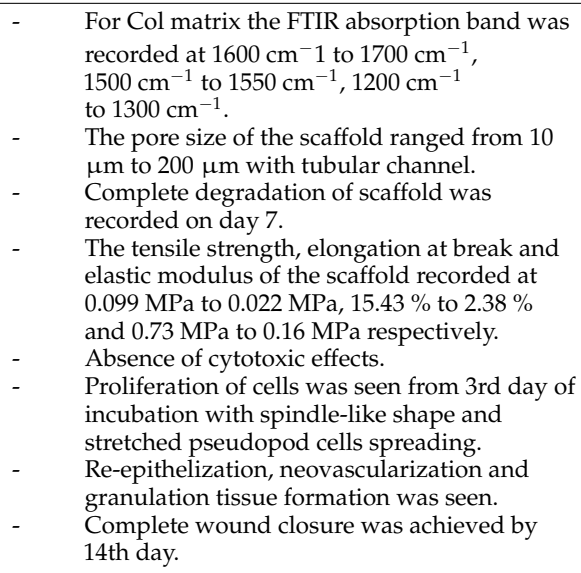 & $\begin{array}{l}\text { Col aids skin } \\
\text { wound healing with } \\
\text { absence of } \\
\text { cytotoxic effect. }\end{array}$ \\
\hline $\begin{array}{l}\text { Zhou et al., } \\
\text { (2016) [100] }\end{array}$ & $\begin{array}{l}\text { To study the } \\
\text { outcome of tilapia } \\
\text { skin derived Col } \\
\text { sponge in } \\
\text { wound healing }\end{array}$ & $\begin{array}{l}\text { In vitro } \\
\text { and } \\
\text { In vivo }\end{array}$ & $\begin{array}{l}\text { Immortalized } \\
\text { human } \\
\text { keratinocytes } \\
(\mathrm{HaCaT}) \text { and } \\
8 \text { male } \\
\text { Sprague } \\
\text { Dawley rats }\end{array}$ & $\begin{array}{l}\text { Up to } \\
28 \text { days }\end{array}$ & $\begin{array}{l}\text { - } \\
\text { The tensile strength of Col nanofiber was } \\
\text { ideal } 6.72 \pm 0.44 \mathrm{MPa} \text {. } \\
\text { The contact angle was recorded at } \\
26.71 \pm 4.88^{\circ} \text {. } \\
\text { - } \quad \text { Absence of immune response for IgG } \\
\text { and IgM. } \\
\text { Thermal stability and swelling capacity } \\
\text { was recorded. } \\
\text { - } \quad \text { FTIR indicated the maintenance of } \alpha \text {-helical } \\
\text { structure after crosslinking. } \\
\text { Rate of cell proliferation (HaCaT) reached } \\
\text { 114\% on 5th day. } \\
\text { Expression of TGase1, filaggrin and } \\
\text { involucrin gene was seen. } \\
\text { Complete wound closure was seen on } \\
\text { 14th day. }\end{array}$ & $\begin{array}{l}\text { Electro-spun tilapia } \\
\text { skin derived Col } \\
\text { enhance rapid } \\
\text { wound healing. }\end{array}$ \\
\hline $\begin{array}{l}\text { Busra et al., } \\
\text { (2019) [41] }\end{array}$ & $\begin{array}{l}\text { To study the } \\
\text { effectiveness of } \\
\text { ovine-derived } \\
\text { Col for full } \\
\text { thickness healing }\end{array}$ & $\begin{array}{l}\text { In vitro } \\
\text { and } \\
\text { in vivo }\end{array}$ & $\begin{array}{l}\text { human } \\
\text { epidermal } \\
\text { keratinocytes } \\
\text { (HDF), } \\
\text { human } \\
\text { dermal } \\
\text { fibroblasts } \\
\text { (HDF) and } 30 \\
\text { athymic/nude }\end{array}$ & $\begin{array}{l}\text { Up to } \\
13 \text { days }\end{array}$ & 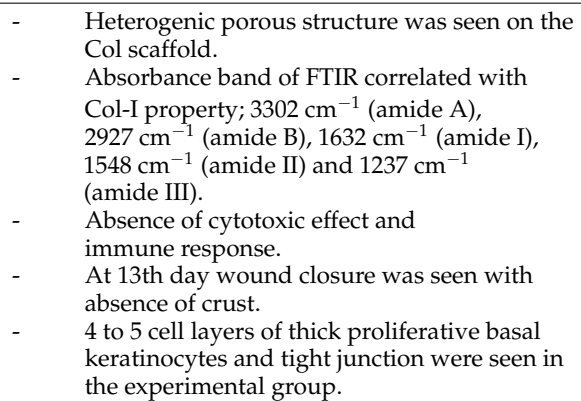 & $\begin{array}{l}\text { Ovine tendon } \\
\text { derived Col; with or } \\
\text { without crosslinkers } \\
\text { enhance } \\
\text { wound healing }\end{array}$ \\
\hline
\end{tabular}


Table 3. Cont

\begin{tabular}{|c|c|c|c|c|c|c|}
\hline Author & Objective & $\begin{array}{c}\text { Study } \\
\text { Design }\end{array}$ & Subject & Duration & Outcome & Conclusion \\
\hline $\begin{array}{l}\text { Pal et al., } \\
\text { (2016) [101] }\end{array}$ & $\begin{array}{l}\text { To study the } \\
\text { outcome of } \\
\text { Mrigal fish } \\
\text { derived Col in } \\
\text { full thickness } \\
\text { wound healing }\end{array}$ & $\begin{array}{l}\text { In vitro } \\
\text { and vivo }\end{array}$ & $\begin{array}{l}\text { Fibroblasts/ } \\
24 \text { adult } \\
\text { Wistar rats }\end{array}$ & $\begin{array}{l}3,5,7,10 \\
\text { and day } 15\end{array}$ & 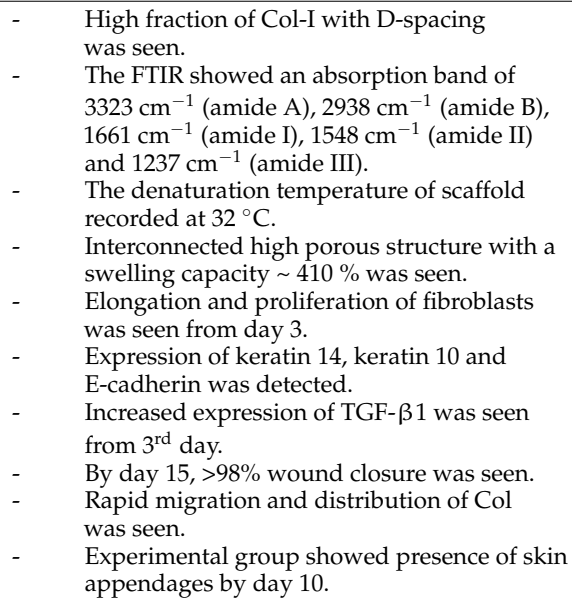 & $\begin{array}{l}\text { Col can increase the } \\
\text { rate of wound } \\
\text { healing, dermal } \\
\text { reconstitution and } \\
\text { re-epithelization. }\end{array}$ \\
\hline $\begin{array}{l}\text { Masry et al., } \\
\text { (2018) [102] }\end{array}$ & $\begin{array}{l}\text { To access the } \\
\text { efficacy of } \\
\text { stabilized Col } \\
\text { matrix (SCM) for } \\
\text { wound healing }\end{array}$ & $\begin{array}{l}\text { In vitro } \\
\text { and } \\
\text { In vivo }\end{array}$ & $\begin{array}{l}\mathrm{HaCaT} \text { and } \\
\text { male } \\
\text { C57BL/6 mice }\end{array}$ & Up to day 14 & 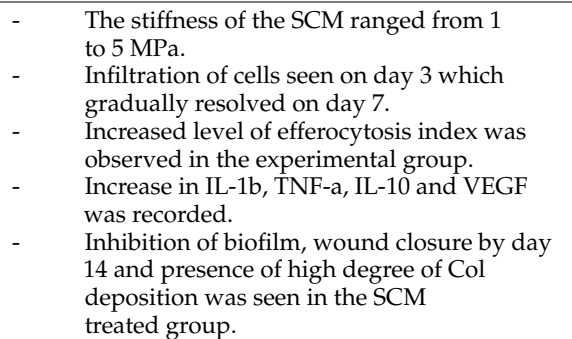 & $\begin{array}{l}\text { Stabilized Col } \\
\text { matrix increase rate } \\
\text { and quality } \\
\text { of healing. }\end{array}$ \\
\hline
\end{tabular}

Table 4. In vitro and in vivo studies of gelatin for skin wound healing.

\begin{tabular}{|c|c|c|c|c|c|c|c|}
\hline Author & Objective & $\begin{array}{c}\text { Study } \\
\text { Design }\end{array}$ & Subject & Duration & & Outcome & Conclusion \\
\hline $\begin{array}{l}\text { Lei et al., } \\
\text { (2019) [93] }\end{array}$ & $\begin{array}{l}\text { To study the } \\
\text { effectiveness of } \\
\text { self- } \\
\text { healing gelatin }\end{array}$ & In vitro & $\begin{array}{l}\text { L929 } \\
\text { cellsand } \\
\text { L02 cells }\end{array}$ & $24 \mathrm{~h}$ and $72 \mathrm{~h}$ & $\begin{array}{l}- \\
- \\
- \\
- \\
- \\
- \\
-\end{array}$ & $\begin{array}{l}\text { FTIR showed absorption band at } 2935 \mathrm{~cm}^{-1} \\
\text { and amide I band at } 1640 \mathrm{~cm}^{-1} \text {. } \\
\text { Healing effectiveness was at } 50 \% \text { at } 40 \text { th } \\
\text { and } 90 \% \text { at } 60 \text { min. } \\
\text { Pore size } \sim 100 \mu \mathrm{m} \text { was seen. } \\
\text { Equilibrium swelling ratio was } \sim 1.28 \text {. } \\
\text { The temperature at the maximum rate of } \\
\text { weight loss } 308.7^{\circ} \mathrm{C} \text {. } \\
\text { Cell viability was }>90 \% \text { up to } 72 \mathrm{~h} \text {. } \\
\text { Absence of cytotoxicity was recorded. }\end{array}$ & $\begin{array}{l}\text { The fabricated } \\
\text { self-healing gelatin } \\
\text { has application } \\
\text { prospects in } \\
\text { biomedical fields. }\end{array}$ \\
\hline $\begin{array}{l}\text { Akhavan- } \\
\text { Kharazian } \\
\text { et al., } \\
(2019) \text { [94] }\end{array}$ & $\begin{array}{l}\text { To characterize } \\
\text { gelatin as a } \\
\text { potential agent } \\
\text { for } \\
\text { wound healing }\end{array}$ & In vitro & $\begin{array}{l}\text { Human fi- } \\
\text { broblast cells }\end{array}$ & 7 days & $\begin{array}{l}- \\
- \\
- \\
- \\
- \\
-\end{array}$ & $\begin{array}{l}\text { FTIR showed absorption band at } \\
3264 \mathrm{~cm}^{-1} \text { (amide A), } 1675 \mathrm{~cm}^{-1} \text { (amide I), } \\
1542 \mathrm{~cm}^{-1} \text { and (amide II). } \\
\text { Addition of chitosan increased the } \\
\text { swelling percentage. } \\
\text { The elastic modulus, tensile strength and } \\
\text { elongation at break were } 1450 \pm 31 \mathrm{MPa} \text {, } \\
47.3 \pm 2.13 \mathrm{MPa} \text { and } 5 \pm 0.2 \% \text {. } \\
\text { WVTR result was } 46.1 \mathrm{~g} / \mathrm{m}^{2} / \mathrm{h} \text {. } \\
\text { A } 16 \mathrm{~mm} \text { diameter of zone of inhibition } \\
\text { was recorded against Escherichia Coli. } \\
\text { Good adhesion of fibroblast cells and } \\
\text { viability was seen up to } 7 \text { days. }\end{array}$ & $\begin{array}{l}\text { Gelatin has the } \\
\text { potential to be } \\
\text { integrated as a } \\
\text { wound } \\
\text { healing material. }\end{array}$ \\
\hline $\begin{array}{l}\text { Hsu et al., } \\
\text { (2019) [95] }\end{array}$ & $\begin{array}{l}\text { To study the } \\
\text { efficacy of gelatin } \\
\text { for wound } \\
\text { healing in } \\
\text { diabetic mice }\end{array}$ & In vivo & $\begin{array}{l}\text { Male } \\
\text { C57BL/6 J } \\
\text { Narl mice }\end{array}$ & $\begin{array}{l}\text { Up to } \\
10 \text { days }\end{array}$ & $\begin{array}{l}- \\
-\end{array}$ & $\begin{array}{l}\text { Porous structure was in the range of } 20 \mu \mathrm{m} \\
\text { to } 300 \mu \mathrm{m} \text {. } \\
\text { FTIR showed absorption bands at } \\
1650 \mathrm{~cm}^{-1} \text { and } 1545 \mathrm{~cm}^{-1} \text { for amide I and } \\
\text { amide II, respectively. } \\
\text { The degradation rate increased } \\
\text { proportionally to the amount } \\
\text { of collagenase. } \\
\text { Thick granulation tissues, increased } \\
\text { re-epithelization and blood vessel } \\
\text { formation were observed in the } \\
\text { treated group. }\end{array}$ & $\begin{array}{l}\text { Gelatin is capable of } \\
\text { contributing to } \\
\text { diabetic wound } \\
\text { healing. }\end{array}$ \\
\hline
\end{tabular}


Table 4. Cont.

\begin{tabular}{|c|c|c|c|c|c|c|c|}
\hline Author & Objective & $\begin{array}{c}\text { Study } \\
\text { Design }\end{array}$ & Subject & Duration & & Outcome & Conclusion \\
\hline $\begin{array}{l}\text { Nikpasand } \\
\text { et al., } \\
\text { (2019) [96] }\end{array}$ & $\begin{array}{l}\text { To access the } \\
\text { outcome of } \\
\text { gelatin } \\
\text { nanocomposite in } \\
\text { wound healing }\end{array}$ & In vivo & 50 male rats & $\begin{array}{l}\text { Up to } \\
21 \text { days }\end{array}$ & $\begin{array}{l}- \\
- \\
-\end{array}$ & $\begin{array}{l}\text { Wound contraction was seen over time } \\
\text { starting from day } 6 \text {. } \\
\text { Re-epithelization and neovascularization } \\
\text { was seen in the experimental group. } \\
\text { High level of mononuclear cells } \\
\text { polymorphonuclear cells and proliferation } \\
\text { of fibroblast cell was seen. } \\
\text { Hydroxyproline content was recorded at } \\
97.88 \pm 3.77 \mathrm{mg} \mathrm{g}^{-1} \text { indicating a high level } \\
\text { of Col deposition. }\end{array}$ & $\begin{array}{l}\text { Gelatin } \\
\text { nanocomposite } \\
\text { accelerates } \\
\text { wound healing. }\end{array}$ \\
\hline $\begin{array}{l}\text { Enrione et al., } \\
\text { (2018) [103] }\end{array}$ & $\begin{array}{l}\text { To study the } \\
\text { efficacy of salmon } \\
\text { gelatin in } \\
\text { wound healing }\end{array}$ & In vivo & $\begin{array}{l}6 \\
\text { Orictholagus } \\
\text { cunicu- } \\
\text { lus rabbits }\end{array}$ & Not specified & $\begin{array}{l}- \\
- \\
- \\
-\end{array}$ & $\begin{array}{l}\text { The pore size was } 185.2 \pm 27.1 \mu \mathrm{m} \\
\text { Young modulus, stress at break and strain } \\
\text { at break were } 150.0 \pm 17.3 \mathrm{MPa}, 316.8 \pm \\
18.4 \mathrm{MPa} \text { and } 2.48 \pm 0.99 \% \text {, respectively. } \\
\text { DSC was recorded at } 318.1 \pm 0.5 \mathrm{~K} \text {. } \\
\text { Up to } 93 \% \text { of wound closure by week } 4 \\
\text { was seen. }\end{array}$ & $\begin{array}{l}\text { Salmon gelatin is a } \\
\text { potential wound } \\
\text { dressing material. }\end{array}$ \\
\hline $\begin{array}{l}\text { Garcia-Orue } \\
\text { et al., } \\
\text { (2019) [104] }\end{array}$ & $\begin{array}{l}\text { To access the } \\
\text { effectiveness of } \\
\text { gelatin } \\
\text { crosslinked with } \\
\text { different agents } \\
\text { for wound } \\
\text { healing }\end{array}$ & $\begin{array}{l}\text { In vitro } \\
\text { and ex } \\
\text { vivo assay }\end{array}$ & $\begin{array}{l}\text { L-929 } \\
\text { fibroblasts } \\
\text { and } \\
\text { redundant } \\
\text { tissue from } \\
\text { patients }\end{array}$ & Up to 8 days & $\begin{array}{l}- \\
- \\
- \\
- \\
- \\
-\end{array}$ & $\begin{array}{l}\text { FTIR showed absorption bands at } \\
1630 \mathrm{~cm}^{-1}, 1530 \mathrm{~cm}^{-1}, 1230 \mathrm{~cm}^{-1} \text { for amide } \\
\text { I, amide II and amide III. } \\
\text { At } 700 \% \text { swelling equilibrium was reached. } \\
\text { WVTR existed in the range of } \\
773.7 \pm 43.4 \mathrm{~g} / \mathrm{m}^{2} \text { day and } \\
787.0 \pm 50.9 \mathrm{~g} / \mathrm{m}^{2} \text {. } \\
\text { Absence of cytotoxicity confirmed through } \\
\text { CCK- } 8 \text { assay. } \\
>70 \% \text { of cell viability was recorded on day } \\
4 \text { and day } 8 \text {. } \\
\text { Increase in cell proliferation markers, } \\
\text { myofibroblast differentiation, cytokeratin } \\
14 \text { and } 10 \text { was seen. }\end{array}$ & $\begin{array}{l}\text { Gelatin hydrofilm } \\
\text { serves as a perfect } \\
\text { biomaterial for } \\
\text { wound dressing. }\end{array}$ \\
\hline $\begin{array}{l}\text { Zeng et al., } \\
\text { (2015) [105] }\end{array}$ & $\begin{array}{l}\text { To access the } \\
\text { effectiveness of } \\
\text { gelatin } \\
\text { microcryogel for } \\
\text { wound healing }\end{array}$ & $\begin{array}{l}\text { In vitro } \\
\text { and } \\
\text { In vivo }\end{array}$ & $\begin{array}{l}\text { human } \\
\text { adipose- } \\
\text { derived stem } \\
\text { cells and } \\
\text { nude mice }\end{array}$ & $\begin{array}{l}\text { Up to } \\
11 \text { days }\end{array}$ & $\begin{array}{l}- \\
- \\
- \\
- \\
-\end{array}$ & $\begin{array}{l}\text { Pore size was } 400 \mu \mathrm{m} \text { width and } \\
500 \mu \mathrm{m} \text { height. } \\
\text { Swelling ratio was recorded at } \\
23.49 \pm 1.57 \% \text {. } \\
\text { Yong modulus was recorded at } \\
8.25 \pm 0.64 \mathrm{KPa} \text {. } \\
>65 \% \text { of adherence of cells to the scaffold } \\
\text { with } 1.5 \mathrm{~h} \text {. } \\
\text { Gene expression study showed increase in } \\
\text { vascular endothelial growth factor (VEGF), } \\
\text { hepatocyte growth factor (HGF), basic } \\
\text { fibroblast growth factor (bFGF) and } \\
\text { platelet-derived growth factor (PDGF) at } \\
\text { 48th hour. }\end{array}$ & $\begin{array}{l}\text { Gelatin } \\
\text { microcryogel } \\
\text { supports } \\
\text { wound healing. }\end{array}$ \\
\hline $\begin{array}{l}\text { Jang et al., } \\
\text { (2017) [97] }\end{array}$ & $\begin{array}{l}\text { To analyse the } \\
\text { effectiveness of } \\
\text { gelatin paste } \\
\text { containing } \\
\text { dermal powder } \\
\text { for } \\
\text { wound healing }\end{array}$ & $\begin{array}{l}\text { In vitro } \\
\text { and } \\
\text { in vivo }\end{array}$ & $\begin{array}{l}\text { Fibroblasts } \\
\text { and Sprague } \\
\text { Dawley rats }\end{array}$ & $\begin{array}{l}18 \text { th and } \\
48 \text { th day }\end{array}$ & $\begin{array}{l} \\
- \\
- \\
- \\
-\end{array}$ & $\begin{array}{l}\text { On } 18 \text { th day, } 85 \% \text { of wound contraction } \\
\text { was seen in the gelatin group. } \\
\text { A thick spinous layer and hyperkeratosis } \\
\text { was seen on day } 48 \text {. } \\
\text { Low level of elastic fibers and blood vessel } \\
\text { formation was seen in the controlled group. } \\
\text { No significant immune response was seen. } \\
\text { Leukocyte values were } 7.28 \pm 3.24 \text { and } \\
8.78 \pm 2.71 \text { for days } 18 \text { and } 48 \text {, respectively. }\end{array}$ & $\begin{array}{l}\text { Gelatin promotes } \\
\text { full thickness } \\
\text { wound healing. }\end{array}$ \\
\hline $\begin{array}{l}\text { Gomes et al., } \\
\text { (2015) [106] }\end{array}$ & $\begin{array}{l}\text { To evaluate the } \\
\text { effectiveness of } \\
\text { gelatin in skin } \\
\text { wound healing }\end{array}$ & $\begin{array}{l}\text { In vitro } \\
\text { and } \\
\text { in vivo }\end{array}$ & $\begin{array}{l}\text { human fetal } \\
\text { fibroblasts } \\
\text { (HFFF2) and } \\
18 \\
\text { Wistar rats }\end{array}$ & Up to week 4 & $\begin{array}{l}- \\
- \\
- \\
- \\
-\end{array}$ & $\begin{array}{l}\text { The porosity was recorded as } 78 \pm 10 \% \\
\text { with a lowest viscosity and highest } \\
\text { conductivity. } \\
\text { Gelatin scaffold was rigid with an elasticity } \\
\text { result of } 162 \pm 96 \mathrm{MPa} \text { and brittle, } \\
\varepsilon=9 \pm 5 \% \text {. } \\
\text { FTIR showed } 3280 \mathrm{~cm}^{-1}, 1640 \mathrm{~cm}^{-1}, \\
1530 \mathrm{~cm}^{-1} \text { and } 1240 \mathrm{~cm}^{-1} \text { for amide A, } \\
\text { amide I, amide II and amide III, } \\
\text { respectively. } \\
\text { Cell viability reduced to } 67 \% \text { on } 2 \text { nd day of } \\
\text { cell seeding. } \\
\text { Continuous cell growth in gelatin scaffold } \\
\text { was seen up to day } 9 \text {. } \\
\text { Cells were scattered in the gelatin scaffold } \\
\text { which then improved in density and } \\
\text { alignment by day } 7 \text {. } \\
\text { Rapid healing was recorded in in vivo } \\
\text { study for gelatin group. } \\
\text { Wound contraction, formation of new } \\
\text { blood vessels and complete healing was } \\
\text { achieved by week } 4 \text {. }\end{array}$ & $\begin{array}{l}\text { Gelatin scaffold } \\
\text { supports full } \\
\text { thickness } \\
\text { wound healing. }\end{array}$ \\
\hline
\end{tabular}




\section{Collagen as a Drug Carrier in the Pharmaceutical Industry}

In the pharmaceutical field, Col modified into nanospheres, nanoparticles or microspheres is used as a device for drug delivery in wound healing which may be formulated either through emulsification, desolvation, coacervation, spray drying, milling technique, fluidization, solvent precipitation method, extrusion, or interfacial polymerization [107]. In this form, they have been proven to be effective in penetrating into the systemic circulation with the aid of Col. This is made possible as the integration of Col has resulted in a larger wound surface area covered due to its small size, high absorption ability and capacity to form a colloidal solution [108]. Apart from this, the crystallite suspension in the gel aggregates emerges as a multiplex chain system in the $\mathrm{Col}$ fold configuration. This characteristic eases the formulation of aggregates into colloidal drug delivery carriers [109]. Meanwhile, the formation of nanospheres is regulated by a blend of different electronic and electrostatic forces, with sodium sulphate acting as the liquefying reagent to allow for maximum charge to charge linkages between DNA plasmid and Col, whereas for Col nanoparticles the molecular weight of the $\mathrm{Col}$ influences the stability of the Col nanoparticles [109]. Nonetheless, changes in $\mathrm{pH}$ and temperature have proven to have significant impact on the molecular weight of the collagen solution and the noncovalent linkage responsible for the collagen's molecular structure during the formation of Col nanoparticles [110].

Col nanoparticle and nanosphere drug delivery carriers are easy to sterilise and, at the same time, they facilitate and accelerate the uptake of exogenous substances. For instance, the uptake of anti-HIV in a variety of cells, specifically from macrophages in antiretroviral therapy in nanotechnology, has always been easy with a Col biomaterial, in comparison to other drug carriers [111]. In addition, Col nanoparticles enhance the delivery of certain drugs such as camptothocin, tetracycline, doxycicline, rolitetracycline, minocycline, amikacin, tobramycin, vancomycin, etc., into the systemic circulation due to its penetration ability into colloidal solution [112]. Conversely, the kinetics in a Col biomaterial are usually influenced by the physical processes, such as swelling to form a gel, polymer hydration via fluid, drug diffusion through the gel formed and eventual erosion of the polymeric gel [113]. For example, the polymer undergoes a relaxation process in an aqueous media, resulting in direct, gradual erodation of the hydrated polymer. It is probable that, like the sponges, it swells and dissolves at the same time, with each of these processes contributing to the overall release mechanism. The diffusion rate of the medium represented by biological fluid in the polymeric sponge, on the other hand, determines the amount of drug released [114]. The main cause of kinetics in this condition is polymeric sponge erosion after water diffusion, as well as the swelling ratio. Aside from that, the drug release kinetics of $\mathrm{Col}$ can be affected by various chemical crosslinkings that affect the degradation rate, such as changes in porosity, density, and other factors [115]. Figure 1 shows the kinetics of drug release from the Col matrix [112]. Table 5 shows the current FDA approved skin healing products from native collagen. 


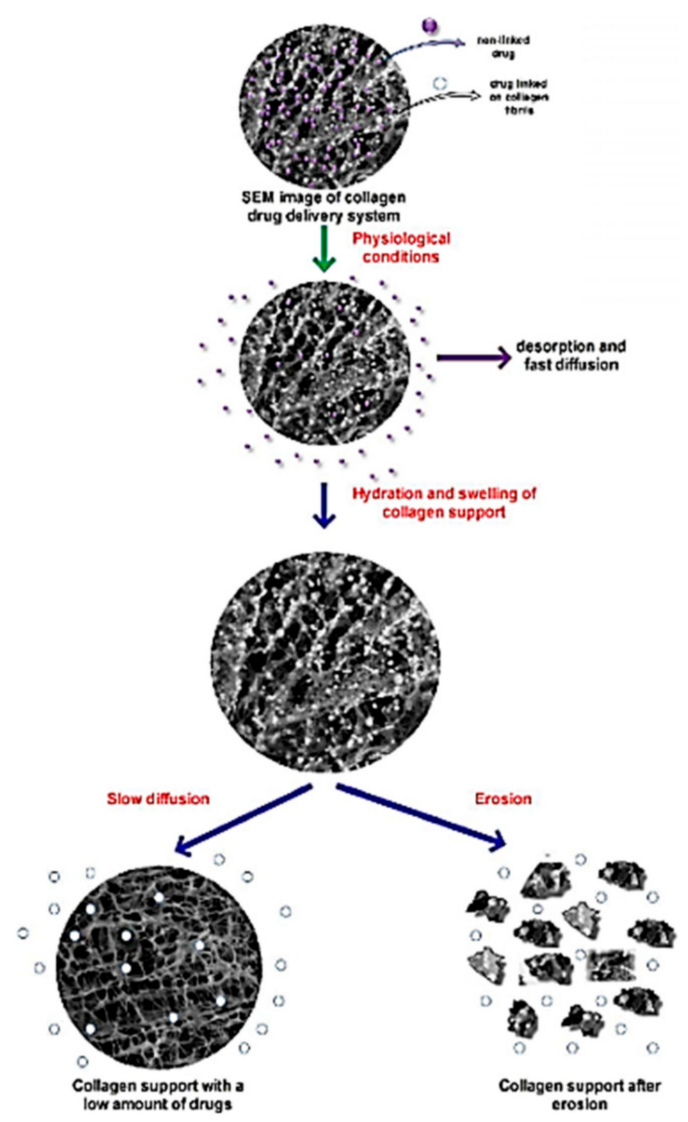

Figure 1. Mechanism of collagen matrix as drug carriers as used under the creative commons attribution 3.0 license [112].

Table 5. Current FDA approved skin healing products from native collagen.

\begin{tabular}{|c|c|c|c|c|c|}
\hline Formulations & Product & $\begin{array}{l}\text { Pharmaceutical } \\
\text { Company }\end{array}$ & Indication & Contraindication & Benefits \\
\hline $\begin{array}{l}\text { Bovine derived } \\
\text { Col type I }\end{array}$ & $\begin{array}{c}\text { HyCol } \\
\text { Collagen Powder }\end{array}$ & Sanara Med Tech Inc. & $\begin{array}{l}\text { Chronic and acute wounds, } \\
\text { partial and full-thickness } \\
\text { wounds, all types of pressure } \\
\text { injuries, venous stasis ulcers, } \\
\text { arterial ulcers, diabetic ulcers, } \\
\text { traumatic wounds, and 1st } \\
\text { degree burns }\end{array}$ & $\begin{array}{l}\text { Not recommended for } \\
\text { those allergic to bovine } \\
\text { derivative products. }\end{array}$ & $\begin{array}{l}\text { Effective, versatile, easy to } \\
\text { apply and compatible. }\end{array}$ \\
\hline $\begin{array}{l}\text { Bovine derived } \\
\text { Col type I }\end{array}$ & $\begin{array}{c}\text { Stimulen } \\
\text { Collagen Powder }\end{array}$ & $\begin{array}{c}\text { Southwest } \\
\text { Technologies Inc. }\end{array}$ & $\begin{array}{l}\text { Partial and full-thickness } \\
\text { wounds, pressure ulcers, venous } \\
\text { ulcers, diabetic ulcers, } \\
\text { partial-thickness burns, acute } \\
\text { wounds, abrasions, and } \\
\text { traumatic wounds }\end{array}$ & $\begin{array}{l}\text { Not recommended for } \\
\text { those allergic to bovine } \\
\text { derivative products. }\end{array}$ & $\begin{array}{l}\text { One time application, prevents } \\
\text { dehydration, ease of usage, } \\
\text { provide moist } \\
\text { microenvironment, } \\
\text { non-cytotoxic nonirritating, } \\
\text { exudates break down the } \\
\text { Col powder. }\end{array}$ \\
\hline $\begin{array}{l}\text { Native equine } \\
\text { type I Collagen }\end{array}$ & Biopad & L\&R USA, Inc. & $\begin{array}{l}\text { Pressure ulcers, venous } \\
\text { insufficiency ulcers, diabetic } \\
\text { ulcers, partial- and full-thickness } \\
\text { wounds, surgical and traumatic } \\
\text { wounds, draining wounds, } \\
\text { lacerations, podiatric, and } \\
\text { post-laser surgery }\end{array}$ & - & $\begin{array}{l}\text { Rapidly heals hard to } \\
\text { heal wounds. }\end{array}$ \\
\hline $\begin{array}{l}\text { Porcine derived } \\
\text { Col type I }\end{array}$ & $\begin{array}{c}\text { Biostep } \\
\text { Collagen Matrix }\end{array}$ & $\begin{array}{l}\text { Smith and } \\
\text { Nephew, Inc. }\end{array}$ & $\begin{array}{c}\text { Full and partial-thickness wound, } \\
\text { pressure ulcers, diabetic ulcers, } \\
\text { venous ulcers, abrasions, } \\
\text { traumatic wounds, dehisced } \\
\text { surgical wounds and 1st and 2nd } \\
\text { degree burns }\end{array}$ & $\begin{array}{l}\text { Not recommended for } \\
\text { those allergic to porcine } \\
\text { derivative products and } \\
\text { 3rd degree burns. }\end{array}$ & $\begin{array}{l}\text { Targets MMPs and optimizes } \\
\text { moisture surface at the injury } \\
\text { site. Ease of application. }\end{array}$ \\
\hline $\begin{array}{l}\text { Bovine derived } \\
\text { Col type I }\end{array}$ & $\begin{array}{l}\text { Collatek } \\
\text { Collagen Gel }\end{array}$ & $\begin{array}{c}\text { Human } \\
\text { BioSciences, Inc }\end{array}$ & $\begin{array}{l}\text { Abrasions, cuts, superficial } \\
\text { injuries, severe sunburns, partial } \\
\text { and full thickness wounds, } \\
\text { venous stasis ulcers, 1st and 2nd } \\
\text { degree burns, ulcers }\end{array}$ & $\begin{array}{l}\text { Not recommended for } \\
\text { those allergic to bovine } \\
\text { derivative products. }\end{array}$ & $\begin{array}{c}\text { Prevents dehydration, } \\
\text { optimizes moisture } \\
\text { microenvironment, fills cavity } \\
\text { wounds, ease of application } \\
\text { and cost effective. }\end{array}$ \\
\hline
\end{tabular}


Table 5. Cont.

\begin{tabular}{|c|c|c|c|c|c|}
\hline Formulations & Product & $\begin{array}{c}\text { Pharmaceutical } \\
\text { Company }\end{array}$ & Indication & Contraindication & Benefits \\
\hline Native Col & Cutimed Epiona & Essity & Full thickness skin loss & - & $\begin{array}{l}\text { 3D matrix that enhances skin } \\
\text { regeneration, decreases } \\
\text { enzymatic degradation, } \\
\text { provides structural support, } \\
\text { and enhances cell proliferation } \\
\text { by creating ECM like structure. }\end{array}$ \\
\hline $\begin{array}{l}\text { Bovine derived } \\
\text { Col type I }\end{array}$ & DermaCol 100 & $\begin{array}{c}\text { DermaRite } \\
\text { Industries, LLC }\end{array}$ & $\begin{array}{c}\text { Full and partial-thickness } \\
\text { wounds, pressure ulcers, diabetic } \\
\text { ulcers, venous ulcers, abrasions, } \\
\text { traumatic wounds, dehisced } \\
\text { surgical wounds and 1st and 2nd } \\
\text { degree burns }\end{array}$ & $\begin{array}{l}\text { Not recommended for } \\
\text { those allergic to bovine } \\
\text { derivative products and } \\
\text { 3rd degree burns. }\end{array}$ & $\begin{array}{l}\text { High absorbent capacity, } \\
\text { optimize moist surface at the } \\
\text { wound site, and aids } \\
\text { hemostatic process. }\end{array}$ \\
\hline $\begin{array}{l}\text { Bovine derived } \\
\text { Col type I }\end{array}$ & $\begin{array}{l}\text { DermaCol } \\
100 \text { Sheet }\end{array}$ & $\begin{array}{c}\text { DermaRite } \\
\text { Industries, LLC }\end{array}$ & $\begin{array}{l}\text { Moderately to heavily exuding } \\
\text { wounds with minor bleeding }\end{array}$ & $\begin{array}{l}\text { Not recommended for } \\
\text { those allergic to bovine } \\
\text { derivative products. }\end{array}$ & $\begin{array}{l}\text { Optimizes moist surface at the } \\
\text { wound site, absorb exudates, } \\
\text { and aids hemostatic process. }\end{array}$ \\
\hline $\begin{array}{l}\text { Bovine derived } \\
\text { Col }\end{array}$ & Gentell Collagen & Gentell & $\begin{array}{l}\text { Burns, sores, blisters, scrapes } \\
\text { and ulcers. }\end{array}$ & $\begin{array}{l}\text { Not recommended for } \\
\text { those allergic to bovine } \\
\text { derivative products. }\end{array}$ & $\begin{array}{c}\text { Regulates MMPs, aids in hard } \\
\text { to heal wounds, and can be } \\
\text { used at any stage of } \\
\text { wound healing. }\end{array}$ \\
\hline $\begin{array}{l}\text { Bovine derived } \\
\text { Col type I }\end{array}$ & $\begin{array}{l}\text { Helix } 3 \text { Bioac- } \\
\text { tive Collagen }\end{array}$ & $\begin{array}{l}\text { Amerx Health } \\
\text { Care Corp. }\end{array}$ & $\begin{array}{l}\text { Burns, sores, blisters, ulcers, and } \\
\text { exuding wounds }\end{array}$ & $\begin{array}{l}\text { Not recommended for } \\
\text { those allergic to bovine } \\
\text { derivative products. }\end{array}$ & $\begin{array}{c}\text { Optimizes moist surface at the } \\
\text { wound site, absorbs exudates, } \\
\text { effective in all wound healing } \\
\text { phases, and available in many } \\
\text { forms such as gels, } \\
\text { powders, etc. }\end{array}$ \\
\hline $\begin{array}{c}\text { Bovine } \\
\text { derived Col }\end{array}$ & $\begin{array}{l}\text { Medifill II Colla- } \\
\text { gen Particles }\end{array}$ & $\begin{array}{c}\text { Human } \\
\text { BioSciences, Inc. }\end{array}$ & $\begin{array}{l}\text { Burns, sores, blisters, scrapes, } \\
\text { and ulcers. }\end{array}$ & $\begin{array}{l}\text { Not recommended for } \\
\text { those allergic to bovine } \\
\text { derivative products. }\end{array}$ & $\begin{array}{l}\text { Absorbing capacity, on shelf } \\
\text { biomaterial, optimizes moist } \\
\text { microenvironment, allows gas } \\
\text { exchange, and cost effective. }\end{array}$ \\
\hline $\begin{array}{l}\text { Bovine derived } \\
\text { Col type I }\end{array}$ & $\begin{array}{l}\text { PuraCol Plus } \\
\text { MicroScaf- } \\
\text { fold Collagen }\end{array}$ & $\begin{array}{l}\text { Medline } \\
\text { Industries, Inc. }\end{array}$ & $\begin{array}{l}\text { Partial and full-thickness } \\
\text { wounds, pressure ulcers, venous } \\
\text { ulcers, diabetic ulcers, donor sites } \\
\text { and other bleeding surface } \\
\text { wounds, abrasions, trauma } \\
\text { wounds, and 1st and 2nd } \\
\text { degree burns. }\end{array}$ & $\begin{array}{l}\text { Not recommended for } \\
\text { those allergic to bovine } \\
\text { derivative products. }\end{array}$ & $\begin{array}{l}\text { Aids in chronic wounds, } \\
\text { exudate absorbing capacity, } \\
\text { optimizes moist } \\
\text { microenvironment, and aids } \\
\text { cell growth. }\end{array}$ \\
\hline
\end{tabular}

Partial and full-thickness wounds, pressure ulcers, venous

Bovine derived PuraCol Medline

Col type I Ultra Powder Industries, Inc
wound, pressure ulcers, ve and other bleeding surface wounds, abrasions, trauma wounds, and 1st and 2nd degree burns.
Not recommended for those allergic to bovine derivative products.
Bioabsorbent, optimizes moist microenvironment, and aids in

regeneration of granulation tissue.
Partial and full-thickness wounds, tunnel or undermined wounds or surgical wounds, low to moderately exuding chronic wounds including diabetic foot

ulcers, venous leg ulcers and sores
Not recommended for those allergic to bovine derivative products.
High exudate absorption, retention provides moist wound healing environment, acts as hemostatic agent, and ease of application.

Sustained adherence,

hypoallergenic, non-pyrogenic, non-toxic, fluid control,

impermeable to exogenous

microorganisms, absorbs exudates, on shelf biomaterial, ease of application, and cost effective.

Bovine Collagen Sheets

BioSciences, Inc.
Burns, sores, blisters, scrapes and ulcers
Not recommended for those allergic to bovin derivative products.
Partial and full-thickness wounds, pressure ulcers, venous ulcers, diabetic ulcers, donor sites and other bleeding surface wounds, abrasions, trauma wounds, and 1st and 2nd degree burns.
Prevents dehydration, optimizes moist

Not recommended for those allergic to animal derivative products.

$\begin{array}{ccc}\begin{array}{c}\text { Animal } \\ \text { derived Col }\end{array} & \text { Stimulen } & \text { Southwest } \\ \text { Collagen Gel } & \text { Technologies, Inc. }\end{array}$

1st and 2nd degree burns, full and partial-thickness wounds, pressure ulcer stages II-IV, pressure ulcer stages II-IV,
diabetic vascular and venous insufficiency ulcers, and light to heavily exudating wounds. icroenvironment, fills cavity
wounds, nontoxic, wounds, nontoxic,
and nonirritating.

Can be customized to any desired size. 


\section{Gelatin as a Drug Carrier in Wound Healing}

Gelatin, being a Col derivative, is highly biocompatible to be inculcated as a drug delivery wound dressing. Specifically, gelatin-based antibacterial wound dressing produced via casting has been proven as an effective dressing material. The outcome indicates it has hydrolytically and thermally stable properties, increased mechanical strength, and exhibits the optimum range of hydrophilicity as well as porosity, which accelerate the healing mechanism [116]. In addition, gelatin crosslinked with diosgenin-conjugated nanocellulose loaded with neomycin shows protection against S. aureus and E.coli in a dose dependent manner. Similarly, the $\mathrm{pH}$ of the biomaterial does influence the release of drugs in this situation. For instance, $60 \%$ of neomycin was released from the gelatin at $\mathrm{pH} 5.5$ while $40 \%$ was released at pH 7.4 within 15 min [117]. Nevertheless, another study shows that combining gelatin with poly( $\varepsilon$-caprolactone) and TGF- $\beta 1$ inhibitor successfully hinders over-proliferation of fibroblasts and wards off scarring. Gelatin nanofibers integrated with silicate particles promoted diabetic wound healing by regulating the release of silicon ions at the wound site [118]. It could be speculated that the nature of the dense and porous novel gelatin-based drug-eluting structures further proves the efficacy of gelatin biomaterial as an ideal drug carrier in wound healing applications.

Nonetheless, this study proves that it is less challenging to modify gelatin into different forms of drug carriers while preserving its natural properties, and particularly the ability to retain moisture at the wound site. These changes can ease the formulation of the microparticle or nanoparticle-based gelatin biomaterial which can be in the form of injection to deliver drugs at the specified location in the body. Along with it, the high waterabsorption capacity of gelatin causes a rapid release profile, which prevents water-soluble medications from being released in a sustained and effective manner. Despite of the different sources of gelatin derivative, initial molecular weight, and degree of crosslinking can all affect water uptake to some extent, which contributes to the healing phase of the wound [119].

\section{Conclusions and Future Prospective}

In the healthcare industry, wound healing is the most critical area as any form of infection can result in severe complications. In this review, the authors compiled the existing knowledge of wound treatment and evaluated them critically to help researchers, clinicians and anyone interested in this field to understand the dynamic wound healing phenomenon, particularly focusing on the roles of the natural substances $\mathrm{Col}$ and gelatin. The authors introduced the principles of an ideal scaffold for wound management, paying particular attention to recent studies of native $\mathrm{Col}$ and gelatin as ideal biomaterials for wound healing. Despite their differing sources of derivative, both $\mathrm{Col}$ and gelatin are said to be ideal scaffolds and highly biocompatible to human cells, due to the integrin molecules. Their numerous properties (cost-efficient, biocompatible, swelling index) and the various manners of their introductions into the human system (electrospun fibers, hydrogels, sponge, films, etc.) contribute to their being favorable options for researchers. However, the uses of $\mathrm{Col}$ and gelatin for wound treatments are holistic approaches which are still at premature levels and lack large-scale clinical trials. The state-of-the-art technology nowadays is the use of biomaterials for 3D printing which imitates the extracellular matrix. The use of 3D-printed skin on a wound could provide an effective alternative in the field of wound care in the near future. Hence, our assessment of the current knowledge of the wound healing process, together with wound microbiology and the present status of wound dressings would be very helpful in the development of more effective wound dressings for individual patients as well as for the continued progress of the medical and pharmaceutical industries.

Author Contributions: Conceptualization, R.N. and H.B.; methodology, R.N.; software, H.B.; validation, P.M.R., H.B. and F.O.; formal analysis, R.N.; investigation, R.N.; resources, H.B.; data curation, H.B.; writing — original draft preparation, R.N.; writing—review and editing, R.N.; visualization, 
P.M.R.; supervision, H.B.; project administration, F.O.; funding acquisition, F.O. All authors have read and agreed to the published version of the manuscript.

Funding: This study was funded through the grant provided by GPutra Fast Track: 9594300 in the form of database subscription. The funders did not make any contribution to the decision to publish or the preparation of the manuscript.

Institutional Review Board Statement: Not applicable.

Informed Consent Statement: Not applicable.

Data Availability Statement: The data presented in this study are available on request from the corresponding author.

Acknowledgments: All the authors would like to express our gratitude to the Faculty of Medicine and Health Science, UPM for the guidance and resources to complete this review and Tan Soon Guan from Research Management Center, UPM for assistantship in proofreading.

Conflicts of Interest: The authors declare no conflict of interest. The funders had no role in the design of the study; in the collection, analyses, or interpretation of data; in the writing of the manuscript, or in the decision to publish the results.

\section{References}

1. Jackson, J.D. Immunology: Host Responses to Biomaterials. In In Situ Tissue Regeneration: Host Cell Recruitment and Biomaterial Design; Lee, S.J., Yoo, J.J., Atala, A., Eds.; Elsevier: Amsterdam, The Netherlands, 2016; pp. 35-47. ISBN 978-0-12-802225-2.

2. Biomaterials Market Size, Share \& Trends Analysis. 2020, pp. 1-190. Available online: https://www.grandviewresearch.com/ industry-analysis/biomaterials-industry (accessed on 10 June 2021).

3. Acevedo, C.A.; Sánchez, E.; Orellana, N.; Morales, P.; Olguín, Y.; Brown, D.I.; Enrione, J. Re-epithelialization appraisal of skin wound in a porcine model using a salmon-gelatin based biomaterial as wound dressing. Pharmaceutics 2019, 11, 196. [CrossRef]

4. Chattopadhyay, S.; Raines, R.T. Collagen-based biomaterials for wound healing. Biopolymers 2014, 101, 821-833. [CrossRef] [PubMed]

5. Meyer, M. Processing of collagen based biomaterials and the resulting materials properties. Biomed. Eng. Online 2019, 18, 1-74. [CrossRef]

6. Deshmukh, S.N.; Dive, A.M.; Moharil, R.; Munde, P. Enigmatic insight into collagen. J. Oral Maxillofac. Pathol. 2016, 20 , $276-283$. [CrossRef]

7. Harley, B.A.; Caliari, S. Collagen-GAG Materials. In Comprehensive Biomaterials; Ducheyne, P., Healy, K., Hutmacher, D.W., Grainger, D.W., Kirkpatrick, C.J., Eds.; Elsevier: Amsterdam, The Netherlands, 2015; Volume 1, pp. 280-300. ISBN 978-0-08055203-3.

8. Chowdhury, S.R.; Mh Busra, M.F.; Lokanathan, Y.; Ng, M.H.; Law, J.X.; Cletus, U.C.; Binti Haji Idrus, R. Collagen Type I: A Versatile Biomaterial. In Novel Biomaterials for Regenerative Medicine, Advances in Experimental Medicine and Biology; Chun, H.J., Ed.; Springer Nature Singapore Pte Ltd.: Gateway East, Singapore, 2018; Volume 1077, pp. 389-414.

9. Rodriguez-Pascual, F.; Slatter, D.A. Collagen cross-linking: Insights on the evolution of metazoan extracellular matrix. Sci. Rep. 2016, 6. [CrossRef]

10. Naomi, R.; Ratanavaraporn, J.; Fauzi, M.B. Comprehensive Review of Hybrid Collagen and Silk Fibroin for Cutaneous Wound Healing. Mater. 2020, 13, 97. [CrossRef] [PubMed]

11. Nikkhah, M.; Akbari, M.; Paul, A.; Memic, A.; Dolatshahi-Pirouz, A.; Khademhosseini, A. Gelatin-Based Biomaterials For Tissue Engineering And Stem Cell Bioengineering. In Biomaterials from Nature for Advanced Devices and Therapies; Wiley Blackwell: Hoboken, NJ, USA, 2016; pp. 37-62. ISBN 9781119126218.

12. Monroy, D.A.P.; Bravo, J.M.C.; Mercado, I.E.S.; Gómez, L.J.V. Gelatin and Collagen Nanofiber Scaffolds for Tissue Engineering. In Tissue Regeneration; Kaoud, H.A.E., Ed.; InTech: Rijeka, Croatia, 2018; ISBN 978-1-83881-486-1.

13. Sulaiman, S.; Chowdhury, S.R.; Fauzi, M.B.; Rani, R.A.; Yahaya, N.H.M.; Tabata, Y.; Hiraoka, Y.; Binti Haji Idrus, R.; Min Hwei, N. 3D Culture of MSCs on a Gelatin Microsphere in a Dynamic Culture System Enhances Chondrogenesis. Int. J. Mol. Sci. 2020, 21, 2688. [CrossRef] [PubMed]

14. Alihosseini, F. Plant-based compounds for antimicrobial textiles. In Antimicrobial Textiles; Elsevier Inc.: Isfahan, Iran, 2016; pp. 155-195. ISBN 9780081005859.

15. Rose, J.B.; Pacelli, S.; El Haj, A.J.; Dua, H.S.; Hopkinson, A.; White, L.J.; Rose, F.R.A.J. Gelatin-based materials in ocular tissue engineering. Mater 2014, 7, 3106-3135. [CrossRef]

16. Bello, A.B.; Kim, D.; Kim, D.; Park, H.; Lee, S.-H. Engineering and Functionalization of Gelatin Biomaterials: From Cell Culture to Medical Applications. Tissue Eng. Part B Rev. 2020, 1-48. [CrossRef]

17. Van Vlierberghe, S.; Graulus, G.J.; Samal, S.K.; Van Nieuwenhove, I.; Dubruel, P. Porous hydrogel biomedical foam scaffolds for tissue repair. In Biomedical Foams for Tissue Engineering Applications; Elsevier Ltd.: Ghent, Belgium, 2014; pp. 335-390. ISBN 9780857096968 . 
18. Radhakrishnan, N.; Kanagesan, S.; Pandurangan, A.; Padmanabhan, P. Basics to different imaging techniques, different nanobiomaterials for image enhancement. In Nanobiomaterials in Medical Imaging; Elsevier: Amsterdam, The Netherlands, 2016; pp. 101-129. ISBN 9780323417389.

19. Zhang, Z.; Ortiz, O.; Goyal, R.; Kohn, J. Biodegradable Polymers. In Principles of Tissue Engineering: Fourth Edition; Elsevier: Amsterdam, The Netherlands, 2014; pp. 441-473. ISBN 9780123983589.

20. Mohiti-Asli, M.; Loboa, E.G. Nanofibrous smart bandages for wound care. In Wound Healing Biomaterials; Elsevier: Amsterdam, The Netherlands, 2016; Volume 2, pp. 483-499. ISBN 9780081006061.

21. Deshmukh, K.; Basheer Ahamed, M.; Deshmukh, R.R.; Khadheer Pasha, S.K.; Bhagat, P.R.; Chidambaram, K. Biopolymer Composites with High Dielectric Performance: Interface Engineering. In Biopolymer Composites in Electronics; Elsevier Inc.: Tamil Nadu, India, 2017; pp. 27-128. ISBN 9780081009741.

22. Fukunishi, T.; Shoji, T.; Shinoka, T. Nanofiber composites in vascular tissue engineering. In Nanofiber Composites for Biomedical Applications; Elsevier Inc.: Columbus, OH, USA, 2017; pp. 455-481. ISBN 9780081002087.

23. Ricard-Blum, S. The Collagen Family. Cold Spring Harb. Perspect. Biol. 2011, 3, 1-19. [CrossRef]

24. Gorgieva, S.; Kokol, V. Collagen vs. Gelatine-Based Biomaterials and Their Biocompatibility: Review and Perspectives. In Biomaterials Applications for Nanomedicine; Pignatello, R., Ed.; InTech: Rijeka, Croatia, 2011; pp. 17-52. ISBN 978-953-307-661-4.

25. Gomez-Guillen, M.C.; Gimenez, B.; Lopez-Caballero, M.E.; Montero, M.P. Functional and bioactive properties of collagen and gelatin from alternative sources: A review. Food Hydrocoll. 2011, 25, 1813-1827. [CrossRef]

26. Grover, C.N.; Cameron, R.E.; Best, S.M. Investigating the morphological, mechanical and degradation properties of scaffolds comprising collagen, gelatin and elastin for use in soft tissue engineering. J. Mech. Behav. Biomed. Mater. 2012, 10, 62-74. [CrossRef] [PubMed]

27. Haug, I.J.; Draget, K.I. Gelatin. In Handbook of Food Proteins; Phillips, G.O., Williams, P.A., Eds.; Elsevier: Trondheim, Norway, 2011; pp. 92-115. ISBN 978-1-84569-758-7.

28. Rodríguez, M.I.A.; Barroso, L.G.R.; Sánchez, M.L. Collagen: A review on its sources and potential cosmetic applications. J. Cosmet. Derm. 2018, 17, 20-26. [CrossRef] [PubMed]

29. Bertazzo, S.; Maidment, S.C.R.; Kallepitis, C.; Fearn, S.; Stevens, M.M.; Xie, H.-N. Fibres and cellular structures preserved in 75-million-year-old dinosaur specimens. Nat. Commun. 2015, 6, 1-8. [CrossRef] [PubMed]

30. Ahmad, M.; Benjakul, S. Extraction and characterisation of pepsin-solubilised collagen from the skin of unicorn leatherjacket (Aluterus monocerous). Food Chem. 2010, 120, 817-824. [CrossRef]

31. Tinrat, S.; Sila-Asna, M. Optimization of gelatin extraction and physicochemical properties of fish skin and bone gelatin: Its application to panna cotta formulas. Curr. Res. Nutr. Food Sci. 2017, 5, 263-273. [CrossRef]

32. Das, M.P.; Suguna, P.R.; Prasad, K.; Vijaylakshmi, J.; Renuka, M. Extraction and Characterization of Gelatin: A Functional Biopolymer. Int. J. Pharm. Pharm. Sci. 2017, 9, 239-242. [CrossRef]

33. Derkach, S.R.; Kuchina, Y.A.; Baryshnikov, A.V.; Kolotova, D.S.; Voron'ko, N.G. Tailoring cod gelatin structure and physical properties with acid and alkaline extraction. Polymers 2019, 11, 1724. [CrossRef]

34. Ahmed, M.A.; Al-Kahtani, H.A.; Jaswir, I.; Tarboush, H.A.; Ismail, E.A. Extraction and characterization of gelatin from camel skin (potential halal gelatin) and production of gelatin nanoparticles. Saudi J. Biol. Sci. 2020, 27, 1596-1601. [CrossRef]

35. Schmidt, M.M.; Dornelles, R.C.P.; Mello, R.O.; Kubota, E.H.; Mazutti, M.A.; Kempka, A.P.; Demiate, I.M. Collagen extraction process. Int. Food Res. J. 2016, 23, 913-922.

36. Cherim, M.; Mustafa, A.; Cadar, E.; Lupașcu, N.; Paris, S.; Sirbu, R. Collagen Sources and Areas of Use. Eur. J. Interdiscip. Stud. 2016, 2, 122-128. [CrossRef]

37. Silvipriya, K.S.; Kumar, K.K.; Bhat, A.R.; Kumar, B.D.; John, A.; Lakshmanan, P. Collagen: Animal Sources and Biomedical Application. J. Appl. Pharm. Sci. 2015, 5, 123-127. [CrossRef]

38. Yang, H.; Shu, Z. The extraction of collagen protein from pig skin. J. Chem. Pharm. Res. 2014, 6, $683-687$.

39. Wang, T.; Lew, J.; Premkumar, J.; Poh, C.L.; Naing, M.W. Production of recombinant collagen: State of the art and challenges. Eng. Biol. 2017, 1, 18-23. [CrossRef]

40. Ramshaw, J.A.M.; Werkmeister, J.A.; Dumsday, G.J. Bioengineered collagens: Emerging directions for biomedical materials. Bioengineered 2014, 5, 227-233. [CrossRef] [PubMed]

41. Busra, F.M.; Rajab, N.F.; Tabata, Y.; Saim, A.B.; Idrus, B.H.R.; Chowdhury, S.R. Rapid treatment of full-thickness skin loss using ovine tendon collagen type I scaffold with skin cells. J. Tissue Eng. Regen. Med. 2019, 13, 874-891. [CrossRef]

42. Rizk, M.A.; Mostafa, N.Y. Extraction and Characterization of Collagen from Buffalo Skin for Biomedical Applications. Orient. J. Chem. 2016, 32, 1601-1609. [CrossRef]

43. Yousefi, M.; Ariffin, F.; Huda, N. An alternative source of type I collagen based on by-product with higher thermal stability. Food Hydrocoll. 2017, 63, 372-382. [CrossRef]

44. Abdelmalek, B.E.; Gómez-Estaca, J.; Sila, A.; Martinez-Alvarez, O.; Gómez-Guillén, M.C.; Chaabouni-Ellouz, S.; Ayadi, M.A.; Bougatef, A. Characteristics and functional properties of gelatin extracted from squid (Loligo vulgaris) skin. LWT Food Sci. Technol. 2016, 65, 924-931. [CrossRef]

45. Chhabra, P.; Tyagi, P.; Bhatnagar, A.; Mittal, G.; Kumar, A. Optimization, characterization, and efficacy evaluation of $2 \%$ chitosan scaffold for tissue engineering and wound healing. J. Pharm. Bioallied Sci. 2016, 8, 300-308. [CrossRef] 
46. Riaz, T.; Zeeshan, R.; Zarif, F.; Ilyas, K.; Muhammad, N.; Safi, S.Z.; Rahim, A.; Rizvi, S.A.A.; Rehman, I.U. FTIR analysis of natural and synthetic collagen. Appl. Spectrosc. Rev. 2018, 53, 703-746. [CrossRef]

47. Prasadh, S.; Wong, R.C.W. Unraveling the mechanical strength of biomaterials used as a bone scaffold in oral and maxillofacial defects. Oral Sci. Int. 2018, 15, 48-55. [CrossRef]

48. Ghodbane, S.A.; Dunn, M.G. Physical and mechanical properties of cross-linked type I collagen scaffolds derived from bovine, porcine, and ovine tendons. J. Biomed. Mater. Res. Part A 2016, 104, 2685-2692. [CrossRef] [PubMed]

49. Xing, Q.; Yates, K.; Vogt, C.; Qian, Z.; Frost, M.C.; Zhao, F. Increasing mechanical strength of gelatin hydrogels by divalent metal ion removal. Sci. Rep. 2014, 4, 1-10. [CrossRef] [PubMed]

50. Cam, C.; Zhu, S.; Truong, N.F.; Scumpia, P.O.; Segura, T. Systematic evaluation of natural scaffolds in cutaneous wound healing. J. Mater. Chem. B 2015, 3, 7986-7992. [CrossRef]

51. Liu, J.; Yan, L.; Yang, W.; Lan, Y.; Zhu, Q.; Xu, H.; Zheng, C.; Guo, R. Controlled-release neurotensin-loaded silk fibroin dressings improve wound healing in diabetic rat model. Bioact. Mater. 2019, 4, 151-159. [CrossRef] [PubMed]

52. Chen, S.; Zhang, Q.; Nakamoto, T.; Kawazoe, N.; Chen, G. Gelatin scaffolds with controlled pore structure and mechanical property for cartilage tissue engineering. Tissue Eng. Part C Methods 2016, 22, 189-198. [CrossRef]

53. Xu, R.; Xia, H.; He, W.; Li, Z.; Zhao, J.; Liu, B.; Wang, Y.; Lei, Q.; Kong, Y.; Bai, Y.; et al. Controlled water vapor transmission rate promotes wound-healing via wound re-epithelialization and contraction enhancement. Sci. Rep. 2016, 6, 24596. [CrossRef]

54. Mousavi, S.; Khoshfetrat, A.B.; Khatami, N.; Ahmadian, M.; Rahbarghazi, R. Comparative study of collagen and gelatin in chitosan-based hydrogels for effective wound dressing: Physical properties and fibroblastic cell behavior. Biochem. Biophys. Res. Commun. 2019, 518, 625-631. [CrossRef]

55. Shakila, J.R.; Jeevithan, E.; Varatharajakumar, A.; Jeyasekaran, G.; Sukumar, D. Comparison of the properties of multi-composite fish gelatin films with that of mammalian gelatin films. Food Chem. 2012, 135, 2260-2267. [CrossRef]

56. Şelaru, A.; Draguşin, D.M.; Olaret, E.; Serafim, A.; Steinmüller-Nethl, D.; Vasile, E.; Iovu, H.; Stancu, I.C.; Costache, M.; Dinescu, $\mathrm{S}$. Fabrication and biocompatibility evaluation of nanodiamonds-gelatin electrospun materials designed for prospective tissue regeneration applications. Materials 2019, 12, 2933. [CrossRef]

57. Ibrahim, M.S.; El-Wassefy, N.A.; Farahat, D.S. Biocompatibility of dental biomaterials. In Biomaterials for Oral and Dental Tissue Engineering; Tayebi, L., Moharamzadeh, K., Eds.; Woodhead Publishing: Milwaukee, WI, USA, 2017; pp. 117-140. ISBN 9780081009673.

58. Tondera, C.; Hauser, S.; Krüger-Genge, A.; Jung, F.; Neffe, A.T.; Lendlein, A.; Klopfleisch, R.; Steinbach, J.; Neuber, C.; Pietzsch, J. Gelatin-based hydrogel degradation and tissue interaction in vivo: Insights from multimodal preclinical imaging in immunocompetent nude mice. Theranostics 2016, 6, 2114-2128. [CrossRef]

59. Holmes, R.; Kirk, S.; Tronci, G.; Yang, X.; Wood, D. Influence of telopeptides on the structural and physical properties of polymeric and monomeric acid-soluble type I collagen. Mater. Sci. Eng. C 2017, 77, 823-827. [CrossRef] [PubMed]

60. Dardelle, G.; Subramaniam, A.; Normand, V. Determination of covalent cross-linker efficacy of gelatin strands using calorimetric analyses of the gel state. Soft Matter 2011, 7, 3315-3322. [CrossRef]

61. Pichler, W.J. Immune pathomechanism and classification of drug hypersensitivity. Allergy Eur. J. Allergy Clin. Immunol. 2019, 74, 1457-1471. [CrossRef] [PubMed]

62. The Editors of Encyclopaedia Hapten. 2019. Available online: https://www.britannica.com/science/hapten (accessed on 10 June 2021).

63. Ge, L.; Xu, Y.; Li, X.; Yuan, L.; Tan, H.; Li, D.; Mu, C. Fabrication of Antibacterial Collagen-Based Composite Wound Dressing. Acs Sustain. Chem. Eng. 2018, 6, 9153-9166. [CrossRef]

64. Ennaas, N.; Hammami, R.; Gomaa, A.; Bédard, F.; Biron, É.; Subirade, M.; Beaulieu, L.; Fliss, I. Collagencin, an antibacterial peptide from fish collagen: Activity, structure and interaction dynamics with membrane. Biochem. Biophys. Res. Commun. 2016, 473, 642-647. [CrossRef] [PubMed]

65. Xu, Z.; Chang, J.; Zhang, P.; Guan, X.; Chen, Y.; Fan, H. Collagen modified with epoxidized safrole for improving antibacterial activity. RSC Adv. 2017, 7, 50300-50306. [CrossRef]

66. Bain, M.A.; Thibodeaux, K.T.; Speyrer, M.S.; Carlson, E.; Koullias, G.J. Effect of Native Type I Collagen with Polyhexamethylene Biguanide Antimicrobial on Wounds: Interim Registry Results. Plast. Reconstr. Surg. Glob. Open 2019, 7, e2251. [CrossRef]

67. Kalirajan, C.; Hameed, P.; Subbiah, N.; Palanisamy, T. Facile Approach to Fabricate Dual purpose Hybrid Materials for tissue engineering and Water Remediation. Sci. Rep. 2019, 9, 1-14. [CrossRef]

68. Hu, X.; Yuan, L.; Han, L.; Li, S.; Song, L. Characterization of antioxidant and antibacterial gelatin films incorporated with: Ginkgo biloba extract. RSC Adv. 2019, 9, 27449-27454. [CrossRef]

69. Yao, Y.; Ding, D.; Shao, H.; Peng, Q.; Huang, Y. Antibacterial Activity and Physical Properties of Fish Gelatin-Chitosan Edible Films Supplemented with D-Limonene. Int. J. Polym. Sci. 2017, 2017, 1837171. [CrossRef]

70. Iimaa, T.; Hirayama, T.; Shirakigawa, N.; Imai, D.; Yamao, T.; Yamashita, Y.I.; Baba, H.; Ijima, H. Antibacterial-agent-immobilized gelatin hydrogel as a 3d scaffold for natural and bioengineered tissues. Gels 2019, 5, 32. [CrossRef]

71. Figueroa-Lopez, K.J.; Castro-Mayorga, J.L.; Andrade-Mahecha, M.M.; Cabedo, L.; Lagaron, J.M. Antibacterial and barrier properties of gelatin coated by electrospun polycaprolactone ultrathin fibers containing black pepper oleoresin of interest in active food biopackaging applications. Nanomaterials 2018, 8, 199. [CrossRef] 
72. Jiang, X.; Wang, Y.; Fan, D.; Zhu, C.; Liu, L.; Duan, Z. A novel human-like collagen hemostatic sponge with uniform morphology, good biodegradability and biocompatibility. J. Biomater. Appl. 2017, 31, 1099-1107. [CrossRef]

73. Li, H.; Cheng, W.; Liu, K.; Chen, L.; Huang, Y.; Wang, X.; Lv, Z.; He, J.; Li, C. Reinforced collagen with oxidized microcrystalline cellulose shows improved hemostatic effects. Carbohydr. Polym. 2017, 165, 30-38. [CrossRef]

74. Totre, J.; Ickowicz, D.; Domb, A.J. Properties and Hemostatic Application of Gelatin. In Biodegradable Polymers in Clinical Use and Clinical Development; Kumar, N., Domb, A.J., Eds.; John Wiley and Sons: Hoboken, NJ, USA, 2011; pp. 91-109. ISBN 9780470424759 .

75. Chen, G.; Kawazoe, N. Preparation of Polymer Scaffolds by Ice Particulate Method for Tissue Engineering. In Biomaterials Nanoarchitectonics; Ebara, M., Ed.; Elsevier: Amsterdam, The Netherlands, 2016; pp. 77-95. ISBN 9780323371278.

76. Gaspar-Pintiliescu, A.; Stefan, L.M.; Anton, E.D.; Berger, D.; Matei, C.; Negreanu-Pirjol, T.; Moldovan, L. Physicochemical and Biological Properties of Gelatin Extracted from Marine Snail Rapana venosa. Mar. Drugs 2019, 17, 602. [CrossRef]

77. Dill, V.; Mörgelin, M. Biological dermal templates with native collagen scaffolds provide guiding ridges for invading cells and may promote structured dermal wound healing. Int. Wound J. 2020, 17, 618-630. [CrossRef]

78. Naomi, R.; Ardhani, R.; Hafiyyah, O.A.; Fauzi, M.B. Current insight of collagen biomatrix for gingival recession: An evidencebased systematic review. Polymers 2020, 12, 2081. [CrossRef]

79. Naomi, R.; Fauzi, M.B. Cellulose/collagen dressings for diabetic foot ulcer: A review. Pharmaceutics 2020, 12, 881. [CrossRef]

80. Coppola, D.; Oliviero, M.; Vitale, G.A.; Lauritano, C.; D’Ambra, I.; Iannace, S.; Pascale, D. de Marine collagen from alternative and sustainable sources: Extraction, processing and applications. Mar. Drugs 2020, 18, 214. [CrossRef]

81. Sow, L.C.; Yang, H. Effects of salt and sugar addition on the physicochemical properties and nanostructure of fish gelatin. Food Hydrocoll. 2015, 45, 72-82. [CrossRef]

82. Hochstein, A.O.; Bhatia, A. (Andy) Collagen: Its Role in Wound Healing. Wound Manag. 2014, 104-109.

83. Gaspar-Pintiliescu, A.; Stanciuc, A.M.; Craciunescu, O. Natural composite dressings based on collagen, gelatin and plant bioactive compounds for wound healing: A review. Int. J. Biol. Macromol. 2019, 138, 854-865. [CrossRef]

84. Gonzalez, A.C.D.O.; Andrade, Z.D.A.; Costa, T.F.; Medrado, A.R.A.P. Wound healing - A literature review. Bras. Derm. 2016, 91, 614-620. [CrossRef]

85. Xue, M.; Jackson, C.J. Extracellular Matrix Reorganization during Wound Healing and Its Impact on Abnormal Scarring. Adv. Wound Care 2015, 4, 119-136. [CrossRef] [PubMed]

86. Udhayakumar, S.; Shankar, K.G.; Sowndarya, S.; Rose, C. Novel fibrous collagen-based cream accelerates fibroblast growth for wound healing applications: In vitro and in vivo evaluation. Biomater. Sci. 2017, 5, 1868-1883. [CrossRef]

87. Wiegand, C.; Buhren, B.A.; Bünemann, E.; Schrumpf, H.; Homey, B.; Frykberg, R.G.; Lurie, F.; Gerber, P.A. A novel native collagen dressing with advantageous properties to promote physiological wound healing. J. Wound Care 2016, 25, 713-720. [CrossRef] [PubMed]

88. Jridi, M.; Bardaa, S.; Moalla, D.; Rebaii, T.; Souissi, N.; Sahnoun, Z.; Nasri, M. Microstructure, rheological and wound healing properties of collagen-based gel from cuttlefish skin. Int. J. Biol. Macromol. 2015, 77, 369-374. [CrossRef]

89. Dang, Q.F.; Liu, H.; Yan, J.Q.; Liu, C.S.; Liu, Y.; Li, J.; Li, J.J. Characterization of collagen from haddock skin and wound healing properties of its hydrolysates. Biomed. Mater. 2015, 10, 015022. [CrossRef]

90. Chen, J.; Gao, K.; Liu, S.; Wang, S.; Elango, J.; Bao, B.; Dong, J.; Liu, N.; Wu, W. Fish collagen surgical compress repairing characteristics on wound healing process in vivo. Mar. Drugs 2019, 17, 43. [CrossRef] [PubMed]

91. Ke, T.; Yang, M.; Mao, D.; Zhu, M.; Che, Y.; Kong, D.; Li, C. Co-Transplantation of Skin-Derived Precursors and Collagen Sponge Facilitates Diabetic Wound Healing by Promoting Local Vascular Regeneration. Cell. Physiol. Biochem. 2015, 37, $1725-1737$. [CrossRef]

92. Helary, C.; Abed, A.; Mosser, G.; Louedec, L.; Letourneur, D.; Coradin, T.; Giraud-Guille, M.M.; Meddahi-Pellé, A. Evaluation of dense collagen matrices as medicated wound dressing for the treatment of cutaneous chronic wounds. Biomater. Sci. 2015, 3, 373-382. [CrossRef] [PubMed]

93. Lei, J.; Li, X.; Wang, S.; Yuan, L.; Ge, L.; Li, D.; Mu, C. Facile Fabrication of Biocompatible Gelatin-Based Self-Healing Hydrogels. ACS Appl. Polym. Mater. 2019, 1, 1350-1358. [CrossRef]

94. Akhavan-Kharazian, N.; Izadi-Vasafi, H. Preparation and characterization of chitosan/gelatin/nanocrystalline cellulose/calcium peroxide films for potential wound dressing applications. Int. J. Biol. Macromol. 2019, 133, 881-891. [CrossRef] [PubMed]

95. Hsu, Y.-Y.; Liu, K.-L.; Yeh, H.-H.; Lin, H.-R.; Wu, H.-L.; Tsai, J.-C. Sustained release of recombinant thrombomodulin from cross-linked gelatin/hyaluronic acid hydrogels potentiate wound healing in diabetic mice. Eur. J. Pharm. Biopharm. 2019, 135, 61-71. [CrossRef]

96. Nikpasand, A.; Parvizi, M.R. Evaluation of the Effect of Titatnium Dioxide Nanoparticles/Gelatin Composite on Infected Skin Wound Healing; An Animal Model Study. Bull. Emerg. Trauma 2019, 7, 366-372. [CrossRef]

97. Jang, H.-J.; Kim, Y.-M.; Yoo, B.-Y.; Seo, Y.-K. Wound-healing effects of human dermal components with gelatin dressing. J. Biomater. Appl. 2018, 32, 716-724. [CrossRef]

98. Wang, C.-H.; Hsieh, D.-J.; Periasamy, S.; Chuang, C.-T.; Tseng, F.-W.; Kuo, J.-C.; Tarng, Y.-W. Regenerative porcine dermal collagen matrix developed by supercritical carbon dioxide extraction technology: Role in accelerated wound healing. Materialia 2020, 9, 100576. [CrossRef] 
99. Akturk, O.; Kismet, K.; Yasti, A.C.; Kuru, S.; Duymus, M.E.; Kaya, F.; Caydere, M.; Hucumenoglu, S.; Keskin, D. Collagen/gold nanoparticle nanocomposites: A potential skin wound healing biomaterial. J. Biomater. Appl. 2016, 31, 283-301. [CrossRef]

100. Zhou, T.; Wang, N.; Xue, Y.; Ding, T.; Liu, X.; Mo, X.; Sun, J. Electrospun tilapia collagen nanofibers accelerating wound healing via inducing keratinocytes proliferation and differentiation. Colloids Surf. B Biointerfaces 2016, 143, 415-422. [CrossRef]

101. Pal, P.; Srivas, P.K.; Dadhich, P.; Das, B.; Maity, P.P.; Moulik, D.; Dhara, S. Accelerating full thickness wound healing using collagen sponge of mrigal fish (Cirrhinus cirrhosus) scale origin. Int. J. Biol. Macromol. 2016, 93, 1507-1518. [CrossRef] [PubMed]

102. Masry, M.S.; El Chaffee, S.; Ghatak, P. Das, Mathew-Steiner, S.S.; Das, A.; Higuita-Castro, N.; Roy, S.; Anani, R.A.; Sen, C.K. Stabilized collagen matrix dressing improves wound macrophage function and epithelialization. J. Fed. Am. Soc. Exp. Biol. 2019, 33, 2144-2155. [CrossRef]

103. Enrione, J.; Pino, K.; Pepczynska, M.; Brown, D.I.; Ortiz, R.; Sánchez, E.; Acevedo, C.A. A novel biomaterial based on salmongelatin and its in vivo evaluation as sterile wound-dressing. Mater. Lett. 2018, 212, 159-164. [CrossRef]

104. Garcia-Orue, I.; Santos-Vizcaino, E.; Etxabide, A.; Uranga, J.; Bayat, A.; Guerrero, P.; Igartua, M.; Caba, K.; de la Hernandez, R.M. Development of Bioinspired Gelatin and Gelatin/Chitosan Bilayer Hydrofilms for Wound Healing. Pharmaceutics 2019, 11, 314. [CrossRef]

105. Zeng, Y.; Zhu, L.; Han, Q.; Liu, W.; Mao, X.; Li, Y.; Yu, N.; Feng, S.; Fu, Q.; Wang, X.; et al. Preformed gelatin microcryogels as injectable cell carriers for enhanced skin wound healing. Acta Biomater. 2015, 25, 291-303. [CrossRef]

106. Gomes, S.R.; Rodrigues, G.; Martins, G.G.; Roberto, M.A.; Mafra, M.; Henriques, C.M.R.; Silva, J.C. In vitro and in vivo evaluation of electrospun nanofibers of PCL, chitosan and gelatin: A comparative study. Mater. Sci. Eng. C 2015, 46, 348-358. [CrossRef]

107. Lengyel, M.; Kállai-Szabó, N.; Antal, V.; Laki, A.J.; Antal, I. Microparticles, microspheres, and microcapsules for advanced drug delivery. Sci. Pharm. 2019, 87, 20. [CrossRef]

108. Pahuja, P.; Arora, S.; Pawar, P. Ocular drug delivery system: A reference to natural polymers. Expert Opin. Drug Deliv. 2012, 9 , 837-861. [CrossRef] [PubMed]

109. Kumar, D. A review on collagen based drug delivery systems. Int. J. Pharm. Teach. Pr. 2013, 4, 811-820.

110. Varanko, A.; Saha, S.; Chilkoti, A. Recent trends in protein and peptide-based biomaterials for advanced drug delivery. Adv. Drug Deliv. Rev. 2020, 156, 133-187. [CrossRef] [PubMed]

111. Mallipeddi, R.; Rohan, L.C. Progress in antiretroviral drug delivery using nanotechnology. Int. J. Nanomed. 2010, 5, 533-547. [CrossRef]

112. Albu, M.G.; Titorencu, I.; Ghica, M.V. Collagen-Based Drug Delivery Systems for Tissue Engineering. In Biomaterials Applications for Nanomedicine; Pignatello, R., Ed.; InTech: Shanghai, China, 2011; pp. 333-358. ISBN 978-953-307-661-4.

113. Aditya, A.; Kim, B.; Koyani, R.D.; Oropeza, B.; Furth, M.; Kim, J.; Kim, N.P. Kinetics of collagen microneedle drug delivery system. J. Drug Deliv. Sci. Technol. 2019, 52, 618-623. [CrossRef]

114. Liechty, W.B.; Kryscio, D.R.; Slaughter, B.V.; Peppas, N.A. Polymers for drug delivery systems. Annu. Rev. Chem. Biomol. Eng. 2010, 1, 149-173. [CrossRef] [PubMed]

115. Unagolla, J.M.; Jayasuriya, A.C. Drug transport mechanisms and in vitro release kinetics of vancomycin encapsulated chitosanalginate polyelectrolyte microparticles as a controlled drug delivery system. Eur. J. Pharm. Sci. 2018, 114, 199-209. [CrossRef] [PubMed]

116. El-Aassar, M.R.; Ibrahim, O.M.; Fouda, M.M.G.; Fakhry, H.; Ajarem, J.; Maodaa, S.N.; Allam, A.A.; Hafez, E.E. Wound dressing of chitosan-based-crosslinked gelatin/ polyvinyl pyrrolidone embedded silver nanoparticles, for targeting multidrug resistance microbes. Carbohydr. Polym. 2020, 255, 117484. [CrossRef] [PubMed]

117. Erdagi, S.I.; Ngwabebhoh, F.A.; Yildiz, U. Genipin crosslinked gelatin-diosgenin-nanocellulose hydrogels for potential wound dressing and healing applications. Int. J. Biol. Macromol. 2020, 149, 651-663. [CrossRef] [PubMed]

118. Echave, M.C.; Hernáez-Moya, R.; Iturriaga, L.; Pedraz, J.L.; Lakshminarayanan, R.; Dolatshahi-Pirouz, A.; Taebnia, N.; Orive, G. Recent advances in gelatin-based therapeutics. Expert Opin. Biol. 2019, 19, 773-779. [CrossRef] [PubMed]

119. Foox, M.; Zilberman, M. Drug delivery from gelatin-based systems. Expert Opin. Drug Deliv. 2015, 12, 1547-1563. [CrossRef] 